\title{
Divergent Market Responses to Human Capital Reorganizations
}

\author{
E. James Cowan (Corresponding author) \\ Silberman College of Business, Fairleigh Dickinson University \\ 285 Madison Avenue, Madison, NJ 07940, USA \\ Tel: 1-973-443-8810 E-mail: ejcowan2@fdu.edu
}

Karen C. Denning

Silberman College of Business, Fairleigh Dickinson University

1000 River Road, Teaneck, NJ 07666, USA

Tel: 1-201-692-7215Ｅ-mail: denning@fdu.edu

Anne Anderson

College of Business and Economics, Lehigh University

27 Memorial Drive West, Bethlehem, PA 18015, USA

Tel: 1-610-758-5936Ｅ-mail: ama6@lehigh.edu

\author{
Xiaohui Yang \\ Silberman College of Business, Fairleigh Dickinson University \\ 285 Madison Avenue, Madison, NJ 07940, USA \\ Tel: 1-973-692-7215_E-mail: xhyang@fdu.edu
}

Received: September 23, 2017 Accepted: October 6, 2017

doi:10.5296/ber.v8i1.11898～URL: https://doi.org/10.5296/ber.v8i1.11898

\section{Abstract}

The stock market response to human capital downsizing events is on average negative. Firms 
maximize value by signalling to investors the types and nature of their capital budgeting decisions. Human capital restructuring is one such capital budgeting signal. This paper expands on previous research by examining market reactions to firm characteristics, specific firm decisions and certain external macroeconomic conditions. We find that the market response to the human capital downsizing events is firm specific and depends on macroeconomic conditions. We confirm our results using robustness testing. For firms responding positively to the downsizing event, size or analyst following, the firm's technological intensity and simultaneous asset reorganization are significant contributors to the market response. For the positive subsample, a positive movement in the business cycle and the commercialization of the internet are associated with positive market returns for downsizing events. Significant factors for firms responding negatively include potential financial distress and offshoring. Technological intensity is also a significant influence, but is different for the two subsamples. For positive responding firms, the market may perceive that the firm is pro-actively managing its costs. For the negative responding firms, the market may perceive that knowledge workers may not be available when and if the firm recovers. For the negative subsample, commercialization of the internet and white-collar outsourcing intensify the negative market response.

Keywords: Restructuring and capital budgeting, Information and market efficiency, Event studies, Analyst coverage

JEL classifications: G14, G31, G32, G34

\section{Introduction}

Previous studies have indicated that there are various drivers for positive and negative market responses to human capital signals. Our motivation for examining this bifurcation of the market response to human capital reorganizations is derived from work by Palmon, Sun and Tang (1997), Marshall, McColgan \& McLeish (2012) and Anderson, Cowan and Denning (2015). Palmon, Sun and Tang (1997) explicitly suggest that investors may view the announcement accompanying a layoff decision as a signal. They also suggest there may be either a decrease or an increase in share value accompanying this layoff announcement. Palmon, Sun and Tang (1997) find that firms that lay off workers due to a decline in demand experience negative stock returns and those that lay off workers in response to efficiency improvements experience positive returns. Marshall, McColgan and McLeish (2012) focus on U.K. firms and find a similar result. Farber and Hallock (2009) suggest that reductions in the firm's work force designed to improve efficiency have become more common over time and those in response to declining product demand less so. Anderson, Cowan and Denning (2015) find this same bifurcation for US human capital restructuring firms. These results reinforce the split between positive and negative performing U.S. firms. ${ }^{1}$

Previous empirical research examines linkages between security market returns and various macroeconomic events. Positive lags, resulting from changes in employment, are evidence of economic expansion. Negative lags are evidence of economic contraction. During times of a

\footnotetext{
${ }^{1}$ For a few additional examples, see Baldwin and Kim (2010), Kneale (2009). De La Merced (2012).
} 
declining economy-wide labor force, the market does not view the firm's reduction of its work force as negatively as it does in times of labor market growth. Marshall, McColgan and McLeish (2012) find a positive relationship between the market response to corporate downsizing and a growing economy and a negative response to human capital reductions during the financial crisis of 2008. Pearce and Roley (1983) find that unemployment news and industrial production have no effect on daily stock prices. Similarly, Hardouvelis (1987) reaches the conclusion that stock responses to nonmonetary, real sector news are very weak. McQueen and Roley (1993) and Boyd, Hu and Jagannathan (2005) document a strong relationship between stock prices and fundamental macro news after allowing for different stages of the business cycle. Flannery and Protopapadakis (2002) find that McQueen and Roley's (1993) results vary considerably with alternative definitions of the economy's condition. Flannery and Protopapadakis (2002) find that seventeen macroeconomic news factors determine stock returns and volatility, but industrial production and GNP are not among these factors. Poitras (2004) finds that there is no state dependence of stock price responses to macroeconomic news, which he believes casts doubt on the robustness of the results in McQueen and Roley (1993) and Boyd, Hu and Jagannathan, (2005). Du, Denning and Zhao (2012) find that the unexpected news component of the Chicago Fed National Activity Index (CFNAI-MA3), as a proxy for macroeconomic news, does affect stock returns. Farber and Hallock (2009) examine 4273 downsizing announcements between 1970 and 1997 and find that announcements of layoffs follow the business cycle.

The contribution of this paper is the segmented examination of firm attributes, related decisions and exogenous macroeconomic events on the market reactions to human capital reductions. Previous literature documents a 55\% (negative) and 45\% (positive) response to those restructurings. From a pragmatic standpoint when senior management makes a decision to engage in human resource restructuring, it should anticipate how the financial markets might react to that decision. Currently, there is no generalized theory about market responses to human capital reductions. We believe our empirical examination will contribute to developing that theory.

We examine 1758 announcements of human capital reductions from 385 firms, which result in a positive or negative market response depending on firm characteristics, decisions or macroeconomic conditions. Section 2 presents the hypotheses; section 3 presents our data, descriptive statistics and methodology; section 4 presents the empirical results; section 5 summarizes our results; and section 6 discusses our conclusions.

\section{Theoretical Discussions and Hypotheses Development}

Previous research documents a statistically significant abnormal market response to work force reductions that may be either positive or negative. We consider whether the positive or negative signal response is dependent on or coincident with firm attributes and decisions, and macroeconomic conditions.

\subsection{Theories and Hypotheses Related to Firm Attributes and Decisions}

This manuscript considers several hypotheses developed from previous literature and the 
popular media. ${ }^{2}$ Firm size $^{3}$, technological intensity ${ }^{4}$ and bankruptcy potential ${ }^{5}$ may be significant contributors to the market response to human capital reorganizations. Prior literature has demonstrated that firm size affects trading volume, volatility and valuations, and should therefore have an attenuating effect on the market response to human capital reductions. ${ }^{6}$ Technological intensity may influence the market response to human capital layoffs, as firms replace excess human capital with a technological process, the resulting decrease in labor costs should cause a positive impact on share price. The probability of bankruptcy may result in human capital reductions with firms managing their costs to improve their financial position, and therefore their stock price. Firms also use capital budgeting and capital structure changes to maximize share value. Information about these decisions along with simultaneous reductions in human capital provide signals to the market that impact share prices. ${ }^{7}$ Specifically, decisions concerning asset changes ${ }^{8}$, financial changes $^{9}$, business focus changes ${ }^{10}$, technology changes ${ }^{11}$, and offshoring ${ }^{12}$ may have an extenuating influence on the market response to work force reductions.

The coincident announcements of these events with those of human capital restructuring should have a positive impact on the market response to the work force reduction as ex-ante we anticipate that firms make stock price maximizing decisions. However, previous literature documents both a positive and negative market response to work force reductions. Therefore, the above decisions should amplify the response in those cases where the market responds positively to the work force reduction and dampen the market response in those cases where the market responds negatively to the work force reduction. Consequently, we empirically examine the total sample and the positive and negative subsamples to determine how the amplification and dampening occurs. Table 1 summarizes the hypotheses concerning announcements of human capital reorganizations and firm attributes and firm decisions.

\footnotetext{
2 See Anderson, Cowan and Denning (2015) for a more expansive discussion of these hypotheses and results.

${ }^{3}$ Hallock (1998) finds that firms that make layoff decisions have several attributes in common and one of them is size.

${ }^{4}$ Mincer (1989) provides evidence concerning the relationship among technological intensity, firm growth and labor market growth. The Paytas and Berglund (2004) classification of technological intensity is used to identify firms by their respective technological intensity.

${ }^{5}$ Lin and Rozeff (1993), Chen, Mehrotra, Sivakumar and Yu (2001) and Denning and Shastri (2011) note that human capital changes typically, but not always, follow a period of declining financial performance.

${ }^{6}$ See Roll (1983).

7 See John, Lang and Netter (1992).

8 For examples, see Agrawal, Jaffe and Mandelker (1999) and Franks, Harris and Titman (1991) for mergers and acquisitions; Kaplan and Weisbach (1992) for divestitures; McConnell and Nantell (1985) for joint ventures. Also see Dyer, Kale and Singh (2001) and Keasler and Denning (2009) for alliances; Allen and McConnell (1998) for carve-outs; Desai and Jain (1999) and Daley, Mehrotra and Sivakumar (1997) for spinoffs.

9 For some examples refer to Bradley, Dsai and Kim (1983) and Lakonishok and Vermaelen (1990) for tender offers; Constantinides and Grundy (1989) and Ikenberry, Lakonishok and Vermaelen (1995) for repurchases; Masulis (1980) and Copeland and Lee (1991) for Exchanges; and Dann and Mikkelson (1984) for capital structure changes.

${ }^{10}$ See Chen, Mehrotra, Sivakumar and Yu (2001).

11 We differentiate between technological intensity and managerial decisions regarding technological change. Technological intensity uses the Paytas and Berglund (2004) classification and self-reported managerial decisions use press release announcements concerning process and product technological change.

12 See Agrawal and Farrell (2003). In the information technology literature, see Dossani and Kenney (2003), and more recently in the economics literature Blinder (2006).
} 
Table 1. Announcements of Human Capital Reorganizations and Firm Attributes and Decisions

\begin{tabular}{|l|l|}
\hline Hypothesis Number & $\begin{array}{l}\text { Null Hypotheses Regarding Human Capital Announcements: } \\
\text { Firm Attributes and Decisions }\end{array}$ \\
\hline 1 & Size of firm has no impact \\
\hline 2 & Bankruptcy potential has no impact \\
\hline 3 & Technological intensity has no impact \\
\hline 4 & Announcement of asset change has no impact \\
\hline 5 & Announcement of financing change has no impact \\
\hline 6 & Announcement of focus change has no impact \\
\hline 7 & Announcement of offshoring decision has no impact \\
\hline 8 & Announcement of technological change has no impact \\
\hline
\end{tabular}

\subsection{Theories and Hypotheses Related to Macroeconomic Exogenous Events}

We consider various exogenous macroeconomic conditions to ascertain the impact of these conditions on security market returns corresponding to human capital downsizing events. Individually, these macroeconomic conditions may have a positive or negative impact on the stock returns. We examine the combined effects and the individual effects in order to determine the impact of, as well as to disentangle the effects of these macroeconomic events on the total sample and the negative and positive subsamples. Casual empiricism indicates the positive and negative market responses to human capital downsizing events do not correspond to any specific calendar time-period. The macroeconomic conditions, however, are by their very nature, time-period dependent and are not necessarily coincident with the human capital event. These differing macroeconomic conditions frequently overlap making it difficult to understand the specific impacts any one of them on the stock market response to human capital reductions. We examine both the individual impacts and the interactions of those impacts in section 3.3.3 in an attempt to disentangle their effects on the market response to human capital reductions.

Included in the macroeconomic analysis are the peace dividend resulting from the end of the cold war, waves of manufacturing and white collar outsourcing, the dotcom boom and bust, the savings and loan (S\&L) collapse and the subprime mortgage debacle, the growing intensity of foreign competition, a variety of regulatory changes and the cyclical nature of the economy. During the cold war period, downsizing should yield a positive response to the reduction in human capital costs; on the other hand, a negative market response is expected from the signal downsizing portends about the loss of government contract revenue. ${ }^{13}$ Therefore, it is an empirical question as to which effect dominates the market response. The manufacturing outsourcing time-period begins in 1987 after a period of rising relative wage

\footnotetext{
${ }^{13}$ The U.S. economy underwent a transition from war to peace. The end of the cold war began during the second half of the 1980s with Mikhail Gorbachev's introduction of glasnost (openness) and perestroika (restructuring) and finally the collapse of the Soviet Union on December 26, 1991 (Gaddis, 2005). As a result, the government cut defense expenditures and the defense industry responded by downsizing and laying off workers. Although this peace dividend had a wide effect on the economy as a whole, the impact on stock returns of workforce reducing firms in the post-cold war period began in 1992 and continued until no firms announced a downsizing in response to the transition to the peace economy in 1997.
} 
rates in the U.S. and continues until Bardhan and Kroll (2003) indicate its conclusion in 1997. ${ }^{14}$ The dotcom boom and subsequent bust includes the time-period from January 1995 to $2001 .^{15}$ The constriction of the financial service industry caused an economic downturn, which may amplify the market response of corporate layoffs. ${ }^{16}$ Foreign competition, as measured by the percent change in international trade, is available beginning in 1996, so this restricts this portion of the analysis to 1996 to $2010 .{ }^{17}$ If firms are competitive, layoffs improve profitability and the market will reward them with increased returns. In contrast, if firms are not competitive, layoffs create a negative market impact. Firms reallocate resources from production to regulatory compliance, when firms decrease labor in periods of increasing regulation. When firms decrease labor in periods of decreasing regulation they are potentially shedding expenses associated with regulatory compliance. ${ }^{18}$ Table 2 summarizes the hypotheses concerning announcements of human capital reorganizations and macroeconomic events.

Table 2. Announcements of Human Capital Reorganizations and Macroeconomic Events

\begin{tabular}{|l|l|}
\hline Hypothesis Number & $\begin{array}{l}\text { Null Hypotheses Regarding Human } \\
\text { Capital Announcements: Macroeconomic Events }\end{array}$ \\
\hline 9 & The cold war peace dividend has no impact \\
\hline 10 & White collar outsourcing has no impact \\
\hline 11 & Manufacturing outsourcing has no impact \\
\hline 12 & Dotcom boom and bust has no impact \\
\hline 13 & The savings and loan collapse has no impact \\
\hline 15 & The subprime mortgage collapse has no impact \\
\hline 16 & Macroeconomic employment growth has no impact \\
\hline 17 & Growth in foreign competition has no impact \\
\hline 18 & Change in government regulation has no impact \\
\hline
\end{tabular}

${ }^{14}$ White-collar outsourcing started in 1996 because of the explosion of the internet. Collectively, firms began to determine which back office functions could be outsourced. U.S. firms found that they could hire highly educated, well-trained and disciplined foreign workers at a fraction of the cost of doing the same function in the U.S.

${ }^{15}$ The need for telecommunications and information technologies increased dramatically as firms virtually integrated. The result of this technological change was the "dotcom bubble" and the employment bubble it caused. The bubble burst due to overcapacity in the long haul telecommunications network, the effects of deregulation due to the Communications Act of 1996, the economic downturn and the failure of demand (Couper, Hejkal, and Wolman, 2003).

${ }^{16}$ Two financial services industry collapses occurred during our sample period: the savings and loan collapse of the 1980s and the subprime mortgage collapse leading to the Great Recession of 2008.

17 When comparable or substitute goods are imported, manufacturing output and hence labor are reduced. This is a perspective commonly heard in the popular press and from the workforce itself.

18 There are significant economy wide regulatory events that occur during sample period. The time-period 1981 to 2002 was one of a substantial decrease in regulation across multiple industries such as the airlines, telecommunications and electrical power distribution. From 2002 to 2007, regulation tended to be stable with some de-regulation continuing in the power distribution industry. Beginning with the Great Recession, more regulation and re-regulation ensued. When firms decrease human capital in periods of increasing (decreasing) regulation a negative (positive) impact on stock returns occurs as a firm downsizes human capital due to increasing (decreasing) regulatory requirements. 


\section{Data Development, Data Descriptive Statistics and Methodology}

Section 3.1 identifies the sources of our data; section 3.2 provides an overview of the event data and bifurcated sample; and section 3.3 develops the regression models and variable definitions.

\subsection{Data Development}

A search of ProQuest U.S. National Newspapers Expanded over the time that it is available (1981 onward) identifies over 100,000 news articles concerning work force reductions. ProQuest National Newspapers Expanded contains 27 national newspapers and 13 databases. We conduct an exhaustive search of ProQuest newspapers using key words such as 'job cuts,' 'layoffs' and 'downsizing,' etc. The resulting listing of downsizing firms contains thousands of public and private firms. Since the number of firms, by the number of announcements across thirty years is an enormous data set, for computational tractability we identify a stratified sample of varying sized firms from the S\&P 500, 400 and 600 over twenty eight years. We believe we have aptly covered the potential sample with our constrained sampling approach and therefore have identified the empirical implications of the downsizing events. For U.S. companies, the S\&P Index Committee inclusion criteria includes: market capitalization, the appropriate amount of at least a 50\% public float, financial transparency, adequate visibility and market price, sector representation, and that the stock is traded on an appropriate exchange. For removal, the Committee considers whether the firm has violated one or more of the criteria for inclusion or whether it is involved in a major asset change such as a merger, acquisition or major restructuring which causes it to violate one of the criteria. ${ }^{19}$

We create a segmented subsample consisting of all U.S. domiciled firms in the Standard \& Poor's indices. We segment our human capital-restructuring sample into the Large Capitalization (S\&P500) Index, the Small Capitalization (S\&P 600) Index and the Mid-Capitalization (S\&P 400) Index during the period January 1981 to March $2010 .^{20}$ This results in a sample of varying asset and market sizes and includes all NAICS industrial classifications. $^{21}$ However, to correct for survivorship bias, we collect the sample backwards in time to 1981, therefore we included all deleted firms from each of the S\&P Indices. For the sample of S\&P firms (current and deleted), an electronic search of all global news sources is conducted for news releases concerning early retirement opportunities, downsizing, job cuts, and layoffs. A firm is included in the sample if it is or was part of an S\&P index, has a human capital reduction in the time-period and is reported in ProQuest National Newspapers Expanded U.S. news source. All data comes from firms with work force reductions that are a minimum of six months apart and the news reporting did not indicate that this reduction was the next step in an on-going layoff plan. Additionally, all firms must have data available in

\footnotetext{
19 See Standard \& Poor's Dow Jones Indices (2013).

${ }^{20}$ We truncate the sample in 2010, retaining the 2011-2017 as a holdout period for future analyses. This allows us to avoid data snooping biases in future research, which is currently ongoing.

${ }^{21}$ NAICS descriptions replaced SIC descriptions beginning in the middle of the sample period consequently we chose to map firms to the NAICS descriptions using the SIC to NAICS Cross Reference tools provided by the United States Census. See also North American Industry Classification System, (1996-2012).
} 
CRSP and Compustat. ${ }^{22}$ Our sample of 385 firms with 1758 events is larger than or comparable to previous studies. ${ }^{23}$

\subsection{Data Descriptive Statistics}

Table 3 delineates the number and composition of firms, events and announcements in our sample. Figure 1 depicts the number of events and employees impacted and Figure 2 depicts the cumulative abnormal returns (CARs) for every event versus the total assets for each firm. Table 4 breaks down the CARs by event window $(0,+1)$ and $(-1,+1)$ for the S\&P 400, S\&P 500 and S\&P 600 for single and multiple event firms. Table 4 also shows the statistical significance of the CARs versus the null hypothesis of no significance and the statistical difference between the subsamples of negative and positive CARs.

For the 2762 S\&P current or deleted firms in the S\&P 400, S\&P 500 and S\&P 600, 385 or $13.9 \%$ announced human capital events - layoffs, job cuts or early retirements (Table 3, Panel A). The majority of sample firms engaging in a work force reduction do so multiple times. ${ }^{24}$ The evidence that most significant events are found in the large capitalization firms (S\&P 500 and S\&P 400) may reflect a combination of larger firms having more employees (with more employees to lay off) or a reporting bias towards greater news coverage of larger firms (Hong, Lim and Stein, 2000, Fang and Peress, 2009 and Derrien and Kecskes, 2013).

\footnotetext{
${ }^{22}$ See Center for Research in Security Prices (CRSP), University of Chicago and Compustat both available from Wharton Research Data Services (WRDS).

${ }^{23}$ For example, see Brookman, Chang and Rennie (2007) with 229 announcements for time 1993-1999 and Brookman, Chang and Rennie (2007b) with 484 announcements for 1993-2003, Chen, Mehrotra, Sivakumar and Yu (2001) with 349 announcements for 1990-1995. Also see Elayan, Swales, Maris, and Scott (1998), Hallock (1998) with 3,242 for 1987-1995, Marshall, McColgan and McLeish (2012) with 67 for 2005-2006 and 76 for 2008, Palmon, Sun and Tang (1997) with 140 for 1982-1990 and Farber and Hallock (2009) with 4273 for 1993-2003. We thank Michele Nestory and Maria Kocylowsky from the Fairleigh Dickinson Business Research Library for identifying the sample sizes and dates.

${ }^{24}$ In ensuing tables, we do not report the results from single event firms. Those results are available from the authors.
} 


\section{MInstitute ${ }_{\text {Mnk }}^{\text {Macrothink }}$}

Business and Economic Research ISSN 2162-4860 2018, Vol. 8, No. 1

Table 3. Panel A: Standard and Poor's Firms with Work Force Reductions--Number and Composition of Firms, Events and Announcements

\begin{tabular}{|l|l|l|l|l|}
\hline Number of Firms & S\&P 400 & S\&P 500 & S\&P 600 & Total \\
\hline Current Index Firms & 400 & 500 & 600 & 1500 \\
\hline Deleted Index Firms & 438 & 225 & 599 & 1262 \\
\hline Total Sample of Firms & 838 & 725 & 1199 & 2762 \\
\hline $\begin{array}{l}\text { Number of Firms with Human } \\
\text { Capital Events }\end{array}$ & $123(14.7 \%)$ & $209(28.3 \%)$ & $53(4.5 \%)$ & $385(100 \%)$ \\
\hline Firms with Single/Multiple Events & $40 / 83$ & $20 / 189$ & $27 / 26$ & $87 / 298$ \\
\hline Number of Announcement of Events & 363 & 1272 & 123 & 1758 \\
\hline $\begin{array}{l}\text { Table 3, Panel B: Firms with Single/Multiple Announcements of Human Capital Restructuring Events } \\
\text { and Simultaneous Asset, Financing, Technology, or Offshoring Change Announcements }\end{array}$ & $17 / 127$ & $12 / 18$ & $56 / 193$ \\
\hline $\begin{array}{l}\text { Firms with Single/Multiple Events \& } \\
\text { Asset Change Announcements }\end{array}$ & $27 / 48$ & $6 / 11$ & $27 / 92$ \\
\hline $\begin{array}{l}\text { Firms with Single/Multiple Events \& } \\
\text { Financial change Announcements }\end{array}$ & $12 / 27$ & $9 / 54$ & $1 / 0$ & $2 / 15$ \\
\hline $\begin{array}{l}\text { Firms with Single/Multiple Events \& } \\
\text { Technology Change Announcements }\end{array}$ & $1 / 6$ & $0 / 9$ & $11 / 17$ & $42 / 165$ \\
\hline $\begin{array}{l}\text { Firms with Single/Multiple Events \& } \\
\text { Offshoring Announcements }\end{array}$ & $18 / 33$ & $13 / 115$ & & \\
\hline
\end{tabular}

Panel A above provides evidence that the S\&P 500 sub-sample of firms with multiple human capital events clearly dominates the sample. There are $725(838,1199)$ firms in the S\&P 500 (S\&P 400, S\&P 600) of which 209 (28.8\%) (123 and 14.7\%, 53 and 4.5\%) made announcements of human capital events. Of the $209(123,53), 20(40,27)$ made a single announcement and $189(83,26)$ firms made multiple announcements. In addition to human capital restructuring announcements, announcements of asset changes, financing changes, technology changes and offshoring events frequently occur contemporaneously (within six months on either side of the announcement event window). Panel B documents that there are 249 (64.4\%, i.e., 56 single and 193 multiple) firms that had coincident announcements of human capital and assets change events. Of the 209 S\&P 500 (123 S\&P 400, 53 S\&P 600) events, there are 144 (68.9\%, 17 single and 127 multiple), 75 (61\%, 27 single and 48 multiple), and 30 (56.6\%, 12 singles and 18 multiples) coincident asset change announcements, respectively. In total, there are also 119 firms with financial change announcements; 17, with technology change announcements; and 207, with offshoring announcements. The breakdown for each type of announcement are 63 S\&P 500 (30.1\%), 39 S\&P 400 (31.7\%) and 17 S\&P600 (32.1\%) firms with coincident financial change announcements; nine $(4.3 \%)$, seven $(5.7 \%)$ and one $(1.9 \%)$ coincident technology change announcements; and there are 128 (61.2\%), 51 (41.5\%), and 28 (52.8\%) coincident offshoring announcements.

Figure 1 depicts the number of event announcements and the number of employees impacted 
by these events. ${ }^{25}$ There are four peak periods for announcements of human capital restructurings and associated impacts on employees: 1) the 2007 to 2009 great recession; 2) the 2001 to 2002 dotcom boom and bust period; 3) the 1998 to 1999 recession and 4) the 1991 to 1992 recession.

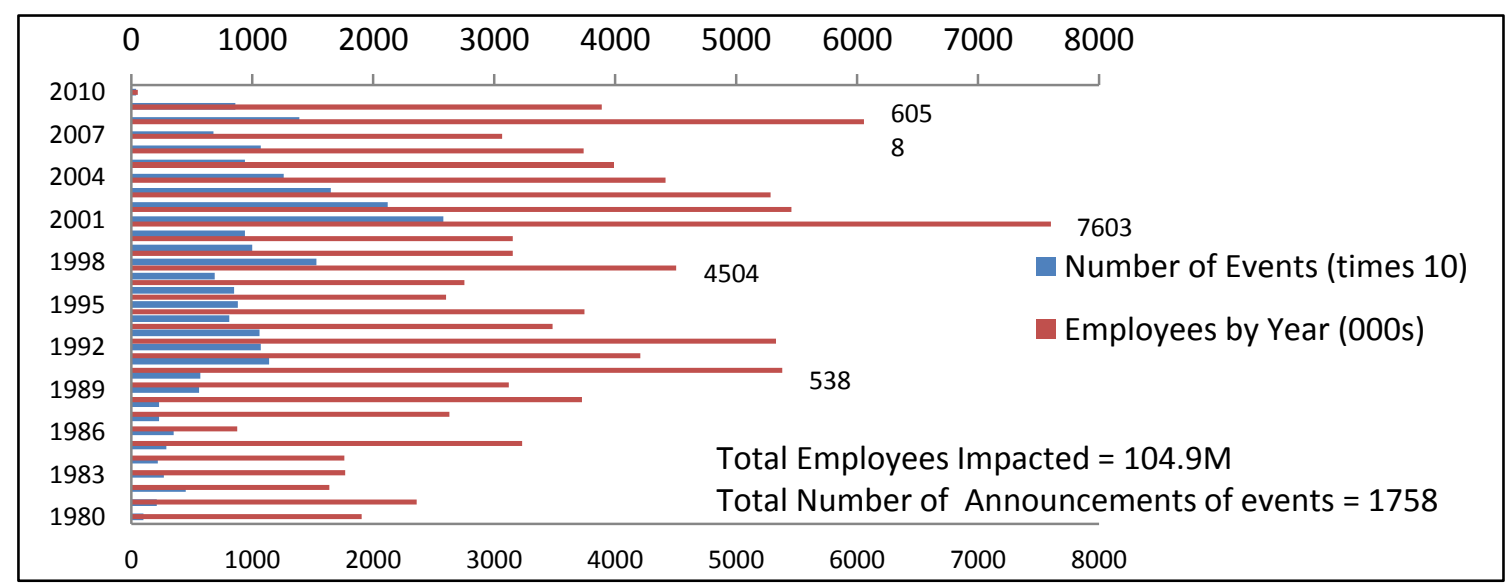

Figure 1. Number of Announcements of Events and Number of Employees Impacted by Year

Comparable to previous studies, Table 4 indicates that our empirical results depict a statistically negative abnormal market response associated with the announcement of work force reductions. ${ }^{26}$ However, our findings show that the investment market response to human capital downsizing events appears to be firm specific. For the overall sample, we find that for both event windows $\mathrm{t}=-1,+1$ and $\mathrm{t}=0,+1$ the cumulative abnormal returns are significant at the $1 \%$ level. However, the results vary by the size of firm. For firms in the S\&P 500, cumulative abnormal returns in both windows are significant at the 5\% level; for the S\&P 400, returns in the $\mathrm{t}=0,+1$ window are significant at the $5 \%$ level; however, for $\mathrm{S} \& \mathrm{P} 600$ firms, only returns in the $\mathrm{t}=-1,+1$ window are significant at the $10 \%$ level. The $\mathrm{Z}$-stat to test the ratio of positive to negative abnormal returns is statistically significant for the S\&P 500 single and multiple events, but only for the window $t=0,+1$ for the single and multiple event S\&P 400 sample. We interpret these findings as consistent with firm specific restructuring results, i.e., in the ensuing analysis we will treat the positive and negative subsamples separately.

\footnotetext{
${ }^{25}$ For ease of scale comparison, we multiply the number of events by ten and divide the number of employees by 1000 .

${ }_{26}$ Farber and Hallock (2009), Marshall, McColgan and McLeish (2012), Anderson, Cowan and Denning (2015).
} 
Table 4. Cumulative Abnormal Return Evidence for Single and Multiple Human Resource Events for S\&P 400, 500, and 600 Firms

\begin{tabular}{|c|c|c|c|c|}
\hline $\begin{array}{l}\text { Event } \\
\text { Window }\end{array}$ & $\begin{array}{l}\text { CAR CRSP value weighted } \\
\text { index as proxy for market } \\
\text { portfolio }\end{array}$ & $\begin{array}{l}\text { \# Positive to \# } \\
\text { Negative }\end{array}$ & $\begin{array}{l}\text { Z-stat for } \\
\text { abnormal return }\end{array}$ & $\begin{array}{l}\text { Z-stat to test ratio of positive } \\
\text { to negative abnormal returns }\end{array}$ \\
\hline \multicolumn{5}{|c|}{ Panel A1: All Single and Multiple Events } \\
\hline$(0,+1)$ & $-0.36 \%$ & $709: 857$ & $-2.692 * * *$ & $-2.638 * * *$ \\
\hline$(-1,+1)$ & $-0.54 \%$ & $712: 854$ & $-2.908 * * *$ & $-2.486 * *$ \\
\hline \multicolumn{5}{|c|}{ Panel A2: Multiple Events Only } \\
\hline$(0,+1)$ & $-0.32 \%$ & 673:810 & $-2.231 * *$ & $-2.493 * *$ \\
\hline$(-1,+1)$ & $-0.49 \%$ & 673:810 & $-2.553 * *$ & $-2.493 * *$ \\
\hline \multicolumn{5}{|c|}{ Panel B1: SP500 Single and Multiple Events } \\
\hline$(0,+1)$ & $-0.20 \%$ & 510:615 & $-1.673 *$ & $-2.191 * *$ \\
\hline$(-1,+1)$ & $-0.35 \%$ & $507: 618$ & $-2.362 * *$ & $-2.370 * *$ \\
\hline \multicolumn{5}{|c|}{ Panel B2: SP500 Multiple Events Only } \\
\hline$(0,+1)$ & $-0.23 \%$ & 502:604 & $-1.776 *$ & $-2.133 * *$ \\
\hline$(-1,+1)$ & $-0.36 \%$ & 497:609 & $-2.345 * *$ & $-2.434 * *$ \\
\hline \multicolumn{5}{|c|}{ Panel C1: SP400 Single and Multiple Events } \\
\hline$(0,+1)$ & $-0.74 \%$ & 140:181 & $2.139 * *$ & $-1.789 *$ \\
\hline$(-1,+1)$ & $-0.58 \%$ & $154: 167$ & -0.870 & -0.226 \\
\hline \multicolumn{5}{|c|}{ Panel C2: SP400 Multiple Events Only } \\
\hline$(0,+1)$ & $-1.22 \%$ & $15: 23$ & $-2.063 * *$ & -1.074 \\
\hline$(-1,+1)$ & $-0.48 \%$ & $18: 20$ & -0.489 & -0.100 \\
\hline \multicolumn{5}{|c|}{ Panel D1: SP600 Single and Multiple Events } \\
\hline$(0,+1)$ & $-0.81 \%$ & $59: 61$ & -0.946 & 0.107 \\
\hline$(-1,+1)$ & $-2.21 \%$ & 51:69 & $-1.803 *$ & -1.354 \\
\hline \multicolumn{5}{|c|}{ Panel D2: SP600 Multiple Events Only } \\
\hline$(0,+1)$ & $-2.53 \%$ & $13: 13$ & -1.046 & 0.157 \\
\hline$(-1,+1)$ & $-3.92 \%$ & $11: 15$ & -1.368 & -0.628 \\
\hline
\end{tabular}

In Table 4, we determine whether there are abnormal market responses associated with the announcement of work force reductions. The estimation window for calculation of abnormal returns includes only firms with a minimum of 100 daily observations. The estimation window of 100 days starts on day $t=-150$ days and continues to day $\mathrm{t}=-51$. Data for inclusion in this table came from firms with work force reductions that are a minimum of six months apart and the news reporting did not indicate that this reduction was the next step in an on-going layoff plan. Column 1 indicates the event window, column 2 the cumulative abnormal return, column 3 the number of firms with positive and negative returns, column 4 the Z-statistic associated with the significance of the abnormal return and column 5 the Z-statistic examining the difference between the number of events with positive and negative returns. Panels A1 and A2 report the results for all sample firms and multiple event firms only, respectively, using a value weighted market portfolio proxy with event windows of $\mathrm{t}=(0$ to +1$)$ and $\mathrm{t}=(-1$ to +1$)$. (Results for the event window $(-5$ to +5$)$ were not statistically significant and are available from the authors. We also used an equally weighted market portfolio and obtained similar results). Panel B considers only the S\&P 500, Panel C the S\&P 400 and Panel D the S\&P 600. We use the Brown and Warner (1985) methodology to calculate the CARs. Three asterisks indicate that the result is statistically significant at the $1 \%$ level; two asterisks, $5 \%$ level; and one asterisk, the $10 \%$ level.

Despite the evidence of significantly negative abnormal returns, the results are not consistent across events with approximately half the sample, independent of firm size, experiencing positive returns. (See Figure 2 below). We interpret these findings and those based on Table 4 
as consistent with firm specific human capital restructuring results. Therefore, in the ensuing analysis we examine the collective sample, but also treat the positive and negative subsamples separately.

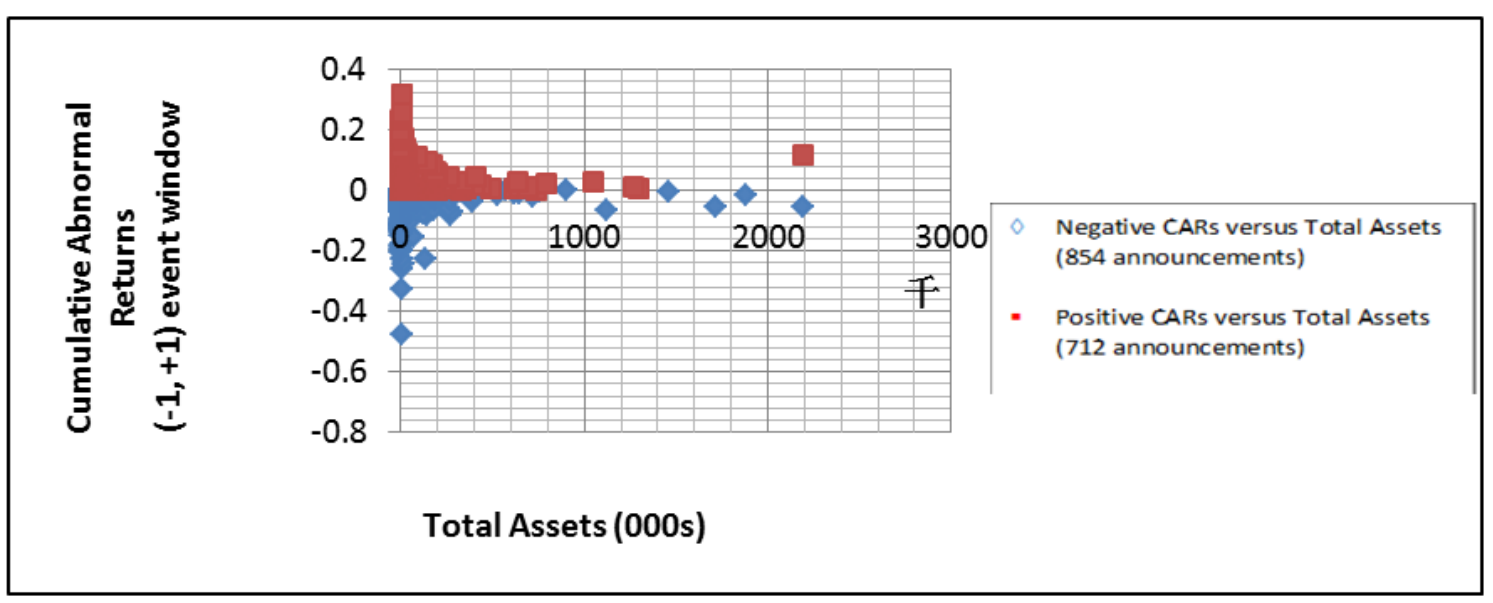

Figure 2. Cumulative Abnormal Returns (CARs) versus Total Assets of the Firm

\subsection{Methodology: Variable Definitions and Regression Models}

Subsection 3.3.1 describes the proxies for firm attributes and proxies for firm decisions, which we use as independent variables in subsection 3.3.2 to estimate the parameters of our first regression models. Subsection 3.3.3 defines the macroeconomic independent dummy variables used in subsection 3.3.4 to estimate the parameters of our second set of regression models. Subsection 3.3.5 motivates the use of the Tobit regression algorithm to estimate the censored, bifurcated subsamples. Subsection 3.3.6 describes a robustness check of our results.

\subsubsection{Variable Proxies for Firm Attributes and Firm Decisions}

Section 3.3.1 considers firm attributes--size, bankruptcy risk and technological intensity, and firm decisions--announcements of asset changes, financial changes, focus changes, technology changes and offshoring. The natural log of firm assets, the natural log of sales and the natural log of market capitalization are the proxies for firm size. The proxy for the financial health of the firm is Altman's Z. We divide the sample into firms with high (above 2.97), medium (between 1.81 and 2.96) and low (below 1.80) values in regression 1.1. ${ }^{27} \mathrm{~A}$ firm's technological intensity is categorized using Paytas and Berglund's (2004) classification scheme, with firms coded 1 if technologically intensive, zero otherwise. Coincident asset change announcements include mergers and acquisitions, divestitures, spin-offs, and other business asset restructurings. If an asset change announcement occurs, we code the dummy variable as 1 , zero otherwise. Coincident financial change announcements include issuances of stock and debt, capital structure changes and substantive write-offs in accounting reports. Coincident announcements of focus changes occur if the firm changes its primary NAICS code or announces a focus change. Self-reporting of technology changes includes

\footnotetext{
27 As an alternative proxy for financial health, we use interest coverage ratios from Compustat and find no substantive differences in results. These results are available from the authors on request. Also see Altman (1968, 1984, 2014a, 2014b).
} 
announcements of both process and product innovations. Offshoring is the act of moving part or all of a business process from the U.S. domestic market to that of another country.

\subsubsection{Regression Model using Firm Attributes and Coincident Firm Decisions}

Cumulative abnormal returns are calculated in the event period $(t=-1$ to $t=+1)$ following the standard Brown and Warner (1985) approach. We estimate abnormal performance using both an equally weighted and a value weighted market model based on daily stock returns from Center for Research in Security Prices (CRSP). We report only value-weighted results. ${ }^{28}$ The estimation period begins on day $\mathrm{t}=-150$ and ends on day $\mathrm{t}=-51$. For the total sample, we report standard Z-tests; and for the positive and negative truncated samples, we provide Chi-squared tests.

Equation 1.1 models the relationships between the CARs and the independent variables. To consider the possibility of multicollinearity among these independent variables we examine their correlation matrix. ${ }^{29}$

$$
\begin{gathered}
\quad c_{i t}=\alpha_{i t}+\beta_{1} s_{i j t}+\beta_{3} v_{i j 3 t}+\beta_{4} v_{i j 4 t}+\beta_{5} v_{i j 5 t}+\beta_{6} v_{i j 6 t}+\beta_{7} v_{i j 7 t}+\beta_{9} v_{i j 9 t}+ \\
\beta_{10} v_{i 6 t} v_{i 7 t}+\beta_{11} v_{i j 6 t} v_{i 10 t}+\beta_{12} v_{i j 5 t} v_{i j 10 t+} \varepsilon_{i t} \\
i=\text { firm }=1, \ldots, n ; j=\text { asset size }=1, \ldots, 3 ; t=\text { time period }=1, \ldots, T .
\end{gathered}
$$

where

$c_{i t}=\mathrm{CAR}$ for firm in in time $\mathrm{t}$

$s_{i j t}=$ Size for firm $\mathrm{i}$ for $\mathrm{j}=$ firm sales, total firm assets or firm market capitalization

$v_{i j 2 t}=$ High Altman's Z for firm i ${ }^{30}$

$v_{i j 3 t}=$ Intermediate Altman's $\mathrm{Z}$ for firm $\mathrm{i}$

$v_{i j 4 t}=$ Low Altman's Z for firm i

$v_{i j 5 t}=$ Technological intensity for firm $\mathrm{i}$

$v_{i j 6 t}=$ Announcement of asset change for firm $\mathrm{i}$

$v_{i j 7 t}=$ Announcement of financing change for firm $\mathrm{i}$

$v_{i j 8 t}=$ Announcement of focus change for firm $\mathrm{i}$

$v_{i j g t}=$ Announcement of offshoring decision for firm $\mathrm{i}$

$v_{i j 10 t}=$ A dummy variable for technological change as reported by firm $\mathrm{i}$

$\alpha, \beta, \gamma, \epsilon=$ intercept, slopes and error terms, respectively.

Included are three interaction terms:

\footnotetext{
${ }^{28}$ The results using equally-weighted CARs are not substantively different and are available from the authors as are the results in alternative event windows.

${ }^{29}$ Due to multicollinearity, we eliminated the announcement of focus change variable $\left(v_{i 8 t}\right)$ from the regression.

${ }^{30}$ Since the dummy variables associated with high, intermediate and low Altman's Z create a multicollinearity problem, the impact of the slope coefficient, $\left(\beta_{2}\right)$ for high Altman's $Z$ is included in the intercept.
} 
$v_{i j 6 t} v_{i j 7 t}=$ Interaction between announcement of asset change and financing decisions

$v_{i j 6 t} v_{i j 10 t}=$ Interaction between announcement of asset change and self-reported technology change dummy

$v_{i j 5 t} v_{i j 10 t}=$ Interaction between technological intensity and self-reported technology change dummy.

\subsubsection{Variable Definitions for Macroeconomic Events}

The regression model uses the following proxy variables to measure the impact of exogenous macroeconomic shocks on the cumulative abnormal returns from announcements of human capital restructurings. These macroeconomic shocks include manufacturing outsourcing in the 1980s and 1990s, the peace dividend following the cold war, the dotcom bubble and the first wave of white-collar outsourcing. Financial market shocks examined are the real-estate bubble of the 1980s and the housing industry bubble and subprime mortgage crisis of the early 2000s. Government regulatory interventions in the marketplace include financial (e.g., Dodd-Frank) and non-financial (e.g., EPA regulations, OSHA, ERISA) events. The percentage change of foreign imports measures the foreign competition the firm faces. We categorize the imports by NAICS code and then estimate the percentage change on a monthly basis. Finally, monthly, lagged employment changes estimate the potential impacts of the business cycle on the CARs. We use one month lagged, percent changes by industry from the Bureau of Labor Statistics Monthly Industry Employment (BLS, 2014).

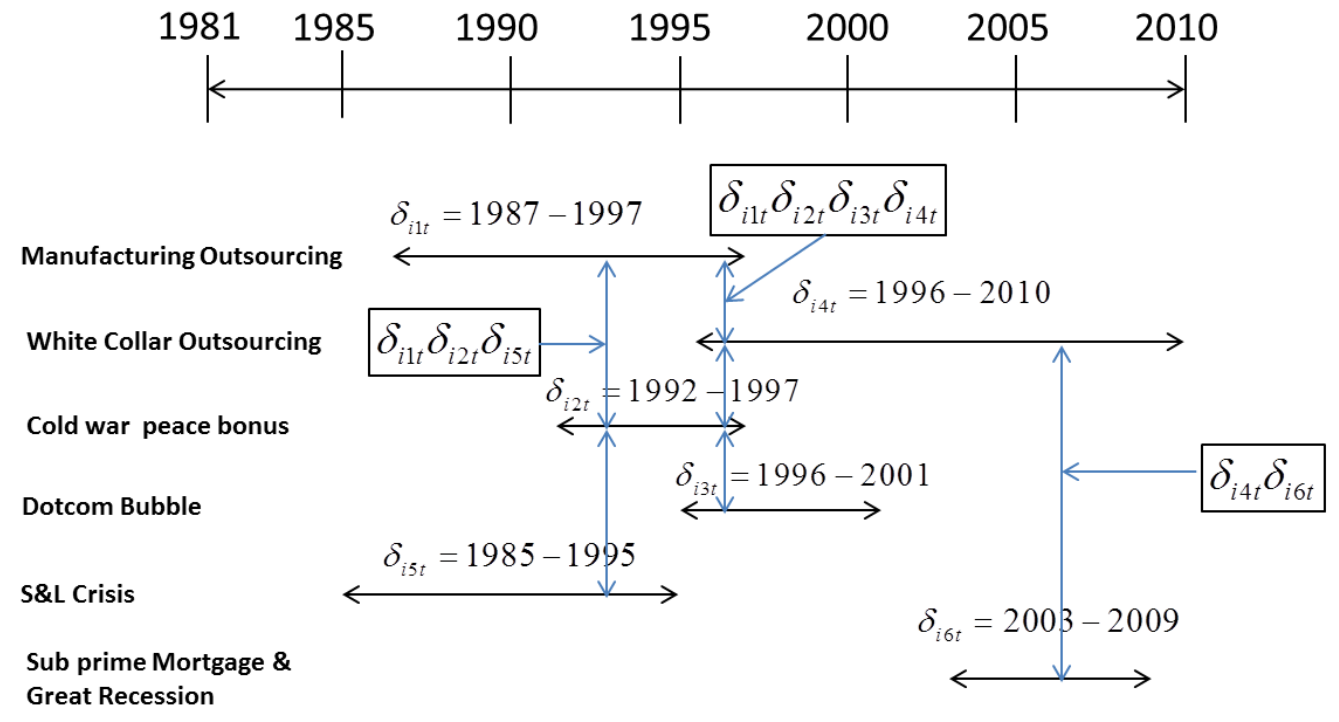

Figure 3. Exogenous Dummy Variable Interaction Effects

As is evident in Figure 3, the exogenous macroeconomic events overlap. We add dummy variable interaction terms to the regression equations in section 3.3.4 below to address the issue of potential multicollinearity. Figure 3 provides some insights into the issue of confounding events and multicollinearity. For example, during the 1996-1997 period, manufacturing outsourcing, the cold war dividend, the dotcom bubble and white-collar outsourcing occurred simultaneously. Two types of responses to examine are the individual 
impact of each event on the market reaction to the human capital restructuring and the compound impact of all four events. We use dummy variables to capture both the individual event and compound events. Examination of the coefficients of the individual and confounding events allow us to disentangle the potential impact of multicollinearity. If the coefficients are not statistically significant and the F-test for the total regression is significantly different from zero, then we identify a condition of multicollinearity and correct for it by eliminating one or more variables. The results in Table 7 allow us to examine the results of multicollinearity in more detail.

\subsubsection{Regressions using Coincident External Macroeconomic Shocks}

Equation 1.2 models the relationships between the CARs and the exogenous variables.

$$
\begin{gathered}
c_{i t}=\alpha_{i t}+\gamma_{1} s_{i j t}+\gamma_{2} \delta_{i j 1 t}+\gamma_{3} \delta_{i j 2 t}+\gamma_{4} \delta_{i j 4 t}+\gamma_{5} \delta_{i j 5 t}+\gamma_{6} \delta_{i j 6 t}+\gamma_{8} \delta_{i j 8 t}+\gamma_{9} \delta_{i j 9 t}+ \\
\gamma_{10} \delta_{i j 1 t} \delta_{i j 2 t} \delta_{i j 3 t} \delta_{i j 4 t}+\gamma_{11} \delta_{i j 1 t} \delta_{i j 2 t} \delta_{i j 5 t}+\gamma_{12} \delta_{i j 4 t} \delta_{i j 6 t}+\varepsilon_{i t}
\end{gathered}
$$

$i=f i r m=1, \ldots, n ; j=$ asset size $=1, \ldots, 3 ; t=$ time period $=1, \ldots, T ;$

where

$c_{i t}=\mathrm{CAR}$ for firm in in time $\mathrm{t}$

$s_{i j t}=$ Size for firm $\mathrm{i}$ for $\mathrm{j}=$ firm sales, total firm assets or firm market capitalization

$\delta_{i j 1 t}=$ Dummy for events during manufacturing outsourcing period

$\delta_{i j 2 t}=$ Dummy for events in the period following the end of the cold war

$\delta_{i j 3 t}=$ Dummy for events during dotcom bubble period (not included due to multicollinearity)

$\delta_{i j 4 t}=$ Dummy for events during white-collar outsourcing period

$\delta_{i j 5 t}=$ Dummy for events during savings and loan (S\&L) crisis period

$\delta_{i j 6 t}=$ Dummy for events during housing subprime loan crisis period

$\delta_{i j 7 t}=$ Dummy indicating whether a regulatory change announcement affecting firm i (not included due to multicollinearity)

$\delta_{i j 8 t}=$ Foreign competition as measured by percent change in international trade ${ }^{31}$

$\delta_{i j 9 t}=$ Lagged percent change in employment by industry

$\alpha, \beta, \gamma, \epsilon=$ intercept, slopes and error terms, respectively.

Included are three interaction terms:

$\delta_{i j 1 t} \delta_{i j 2 t} \delta_{i j 3 t} \delta_{i j 4 t}=$ Interactions among manufacturing outsourcing, cold war, dotcom bubble and white-collar outsourcing

$\delta_{i j 1 t} \delta_{i j 2 t} \delta_{i j 5 t}=$ Interactions among manufacturing outsourcing, cold war and S\&L crisis

$\delta_{i j 4 t} \delta_{i j 6 t}=$ Interactions between white-collar outsourcing and subprime mortgage dummy. ${ }^{31}$ Note that the variable and related slope for foreign competition $\left(v_{i j 6 t}, \beta_{6}\right)$ is excluded, since the variable was
available for only a portion (1996-2010) of the sample period. 


\subsubsection{Tobit Regressions}

For the total sample, ordinary least squares regression is used to document that our sample results are substantively the same as in previous research (see Table 5 below), that is on average our sample generates a negative market response to the human capital downsizing event. Our innovations are the aforementioned analysis of external macroeconomic events and the analysis of both the positive and negative subsamples returns using Tobit regressions (Tobin, 1958) Censoring the data and using Tobit is appropriate since both our positive and negative CARS are small and close to zero. Tobit provides a method for addressing a censored sample with many of the left hand side variables close to zero and provides the basis for extracting more information from the conditional regression than from an ordinary least squared regression. ${ }^{32}$ McDonald and Moffitt (1980) show that Tobit provides estimates that include more information at the limit, as well as information above the limit (p. 318). We use the STATA ${ }^{\circledR}$ Tobit algorithm to extend the Tobit regression to allow for observations close to zero and below the limit as well (UCLA, 2016). ${ }^{33}$ Finally, we address the issue of multicollinearity by splitting the sample into negative and positive subsamples and examining the coefficients and summary statistics. ${ }^{34}$

\subsubsection{A Robustness Check: An Alternative Specification using Mediator and Moderator} Variables

We modify Baron and Kenny's (1986) three-step approach discussed below as a test of robustness of our results. ${ }^{35}$ A mediator or moderator variable changes the relationship between an independent variable and a dependent variable. The figure below provides a visual depiction of the relationships among the three variables:

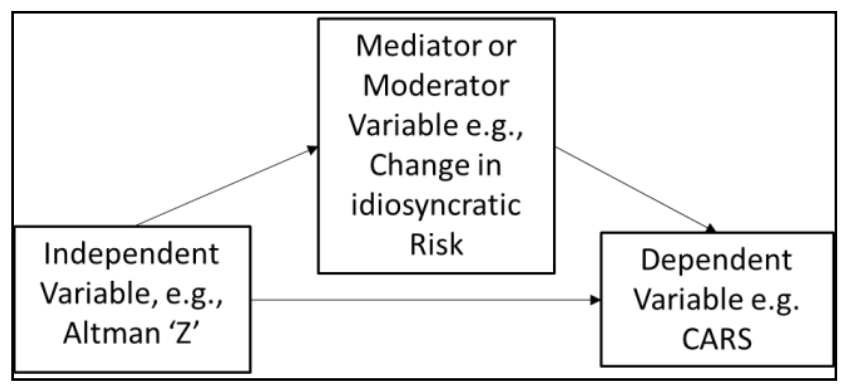

Figure 4

In this example, the independent variable (Altman's Z) works through the mediator variable (change in idiosyncratic or private risk) to modify the explanation of how the independent variable explains the dependent variable. We base our independent and dependent variables in finance theory and research. ${ }^{36}$ Intuitively firms experiencing financial challenges (low Altman's Z) are ones that would experience changes in firm specific risk and potentially lay

\footnotetext{
32 See McDonald and Moffitt, 1980.

33 STATA® Data Analysis and Statistical Software by StataCorp LP.

34 See Theil (1971, p. 181) for how segmenting the sample addresses the multicollinearity issue.

35 We thank an anonymous referee for suggesting this approach.

${ }^{36}$ For applications of idiosyncratic risk, see Ashbaugh-Skaife, H., Collins, D. W., Kinney, W. R. and Lanford, R. (2009), Chichernea, D. C., Ferguson, M. F. and Kassa, H. (2015), Denning, K. C., Hulburt, H. and Ferris, S. P. (2006), Herskovic, B., Kelly, B. T., Lustig, H. N. and Van Nieuwerburgh, S. (2016) and Meucci, A. (2014).
} 
off workers to ameliorate these conditions. Appendix A contains a more thorough description of the Baron and Kenny approach.

\section{Empirical Results and Analyses}

In section 4, we discuss results that provide the basis for examination of the null hypotheses depicted in Tables 1 and 2. In section 4.1, we examine firm attributes and coincident firm decisions using the total sample and the negative and positive subsamples. In section 4.2, we examine the potential influence of macroeconomic events; and in section 4.3, we provide the results of our robustness analysis.

\subsection{Human Capital Reductions, Firm Attributes and Coincident Firm Decisions}

\subsubsection{Total Sample Results for Firm Attributes and Decisions}

Recall that the average market response to layoffs is negative (see Table 4). Columns 2 and 3 of Table 5 present empirical evidence regarding the coincident impacts of layoffs and firm attributes and decisions. The overall regression has an F-statistic of 1.73, which is not significant at a 5\% level or better. Note that the proxy for firm size (total firm assets) and the intercept are statistically significant at the $1 \%$ level; offshoring at the 5\% level; intermediate Altman's Z and low Altman's Z statistics at the 10\% level; and announcement of asset changes, at the $10 \%$ level. ${ }^{37}$ Offshoring reinforces the market's negative reaction suggesting that the market dislikes a firm's actions to offshore its operations; whereas, a firm's recognition that it is in financial distress dampens the associated negative market response. The market responds to this news as a signal that the firm may take appropriate actions to manage the challenges it faces. When we split the sample into the negative and positive subsamples (columns $4-7$ ), we find that the Chi-squared statistic is significant for the negative subsample at better than the $1 \%$ level. ${ }^{38}$ The market seems to respond more strongly to negative news than to positive news. Note that the intercept for the total, positive and negative samples are statistically significant, and indicative of firm attributes and decisions not providing a thorough explanation of the market response to corporate downsizing.

\subsubsection{Positive Returns Subsample Results for Firm Attributes and Decisions}

Table 5 provides further evidence for the positive subsample regression (columns 4 and 5). The size proxy at the $1 \%$ level and the asset change dummy variable at the $10 \%$ level. ${ }^{39}$ For the positive subsample results, technological intensity does provide additional explanatory power. As firms perceived by the market as doing well lay off workers, the market seems to believe that management is taking the necessary steps to manage costs. This finding of a relationship between the market's response to announcements of layoffs by firms in the positive subsample and technological intensity is new and suggests that when technologically intensive firms reduce their labor force and labor costs, the market responds positively. We

\footnotetext{
37 Note that the high Altman's Z statistic is contained within the intercept, along with any other omitted variables.

38 With the exception of the Altman's Z results, these findings are consistent with Anderson, Cowan and Denning (2015).

${ }^{39}$ See footnotes 3 and 7 for references regarding size and asset change research.
} 
conjecture that technologically intensive firms substitute capital for labor and reduce the overall cost structure of the production process.

Table 5. Human Capital Reductions: Market reaction results based on Firm Attributes and Decisions

\begin{tabular}{|c|c|c|c|c|c|c|}
\hline \multirow[b]{2}{*}{ Hypotheses } & \multicolumn{2}{|c|}{ Total Sample } & \multicolumn{2}{|c|}{ Positive Subsample } & \multicolumn{2}{|c|}{ Negative Subsample } \\
\hline & $\begin{array}{l}\text { Coefficient } \\
\text { (t-statistic) }\end{array}$ & $P>|t|$ & $\begin{array}{l}\text { Coefficient } \\
\text { (t-statistic) }\end{array}$ & $P>|t|$ & $\begin{array}{l}\text { Coefficient } \\
\text { (t-statistic) }\end{array}$ & $P>|t|$ \\
\hline Size (natural log of assets) & $\begin{array}{c}0.00414 * * * \\
(3.0)\end{array}$ & 0.003 & $\begin{array}{c}-0.00469 * * * \\
(-2.83)\end{array}$ & 0.005 & $\begin{array}{l}0.00899 * * * \\
(6.62)\end{array}$ & 0.000 \\
\hline Intermediate Altman's Z & $\begin{array}{c}0.02274^{*} \\
(1.6)\end{array}$ & 0.096 & $\begin{array}{c}0.01218 \\
(0.76)\end{array}$ & 0.447 & $\begin{array}{c}0.01577 \\
(1.11)\end{array}$ & 0.111 \\
\hline Low Altman's Z & $\begin{array}{c}0.2169 * \\
(1.77)\end{array}$ & 0.077 & $\begin{array}{c}0.00010 \\
(0.07)\end{array}$ & 0.945 & $\begin{array}{c}0.02274^{*} \\
(1.80)\end{array}$ & 0.072 \\
\hline Tech Intensity & $\begin{array}{c}-0.00468 \\
(-1.02) \\
\end{array}$ & 0.307 & $\begin{array}{c}0.01116 * * \\
(2.10)\end{array}$ & 0.036 & $\begin{array}{c}-0.01984 * * * \\
(-4.13)\end{array}$ & 0.000 \\
\hline Tech Change Announcement & $\begin{array}{c}0.0078 \\
(0.60) \\
\end{array}$ & 0.552 & $\begin{array}{c}0.00321 \\
(0.23) \\
\end{array}$ & 0.818 & $\begin{array}{c}-0.00303 \\
(-0.20) \\
\end{array}$ & 0.841 \\
\hline Asset Change Announcement & $\begin{array}{c}0.00865^{*} \\
(1.78) \\
\end{array}$ & 0.076 & $\begin{array}{c}0.00982 * \\
(1.68)\end{array}$ & 0.093 & $\begin{array}{c}0.00139 \\
(0.28)\end{array}$ & 0.781 \\
\hline Financial change Announcement & $\begin{array}{c}0.00168 \\
(0.18) \\
\end{array}$ & 0.856 & $\begin{array}{c}0.00590 \\
(0.56)\end{array}$ & 0.579 & $\begin{array}{c}-0.00950 \\
(-0.98)\end{array}$ & 0.328 \\
\hline Offshoring Announcement & $\begin{array}{c}-0.00885^{* *} \\
(-1.92)\end{array}$ & 0.055 & $\begin{array}{c}-0.00101 \\
(-0.19) \\
\end{array}$ & 0.853 & $\begin{array}{c}-0.01048 * * \\
(-2.20)\end{array}$ & 0.028 \\
\hline Asset-Fin Interaction & $\begin{array}{c}-0.00493 \\
(-0.48) \\
\end{array}$ & 0.635 & $\begin{array}{c}-0.00663 \\
(-0.55) \\
\end{array}$ & 0.580 & $\begin{array}{c}-0.00025 \\
(-0.02) \\
\end{array}$ & 0.981 \\
\hline Asset-Tech Interaction & $\begin{array}{c}-0.01379 \\
(-0.090)\end{array}$ & 0.371 & $\begin{array}{c}-0.00357) \\
(-0.20)\end{array}$ & 0.843 & $\begin{array}{c}-0.00145) \\
(-0.09)\end{array}$ & 0.930 \\
\hline Tech Intensity-Tech Change Interaction & $\begin{array}{c}-0.00591 \\
(-0.36)\end{array}$ & 0.719 & $\begin{array}{c}-0.02057 \\
(-1.01)\end{array}$ & 0.315 & $\begin{array}{c}0.01671 \\
(1.00)\end{array}$ & 0.316 \\
\hline Intercept & $\begin{array}{c}-0.05998 * * * \\
(-3.42)\end{array}$ & 0.001 & $\begin{array}{c}0.06811 * * * \\
(3.30)\end{array}$ & 0.001 & $\begin{array}{c}-0.12556 * * * \\
(-7.55)\end{array}$ & 0.000 \\
\hline Number of Observations & \multicolumn{2}{|l|}{1265} & \multicolumn{2}{|l|}{564} & \multicolumn{2}{|l|}{701} \\
\hline F-statistic & \multicolumn{2}{|l|}{1.73} & \multicolumn{2}{|l|}{--} & \multicolumn{2}{|l|}{--} \\
\hline Probability > F & \multicolumn{2}{|l|}{0.061} & \multicolumn{2}{|l|}{--} & \multicolumn{2}{|l|}{--} \\
\hline LR Chi2 & \multicolumn{2}{|l|}{--} & \multicolumn{2}{|l|}{18.03} & \multicolumn{2}{|l|}{75.82} \\
\hline Probability > Chi2 & \multicolumn{2}{|l|}{--} & \multicolumn{2}{|l|}{0.0808} & \multicolumn{2}{|l|}{0.0000} \\
\hline Adjusted $\mathrm{R}^{2}$ & \multicolumn{2}{|c|}{0.0064} & \multicolumn{2}{|l|}{--} & \multicolumn{2}{|l|}{--} \\
\hline
\end{tabular}

In Table 5, we present evidence of regressions of the cumulative abnormal returns against various firm attributes and firm decisions for the total sample and negative and positive subsamples. Data for inclusion in this table come from firms with multiple work force reductions that are a minimum of six months apart and the news reporting did not indicate that this reduction was the next step in an on-going layoff plan. We show results for $t$ $=(-1$ to +1$)$. Results for $t=(0$ to +1$)$ and $t=(-5$ to +5$)$ are directionally the same but with lower explanatory power. We use the both the firm's total assets and sales as proxies for firm size. (We also used interest coverage ratios, as well as Altman's Z, for a measure of financial distress. These results are available from the authors.) Each model considers abnormal returns based on value weighted (VW) market returns. (Results based on equally weighted returns and those in the alternative event windows are available from the authors). t-statistics are in parentheses below the parameter estimates. For the total sample, we use OLS; for the positive and negative censored subsamples, we use a Tobit regression from STATA®. Note we exclude the focus change variable from the regression due to collinearity problems and any effects would be included in the intercept. $\ddagger$ 
Number of observations is dependent on the availability of CRSP and Compustat data. * significant at $10 \%, * *$ significant at $5 \%, * * *$ significant at $1 \%$.

\subsubsection{Negative Returns Subsample Results for Firm Attributes and Decisions}

Table 5 (columns 6 and 7) also presents the results for the negative subsample regression. The technological intensity proxy continues to be significant at the $1 \%$ level but in the opposite direction from the positive subsample regression. For firms in the negative subsample, the market may perceive that laying off people in technology intensive firms is a poor decision. If firms recover, the previous layoff of knowledge workers may limit the firms' ability to grow. Further, when firms perform poorly and announce an offshoring decision, the market reaction is also significant and negative and indicates that the market dislikes decisions to offshore when the firm is under financial distress. The market may view offshoring as a cost reduction mechanism, which amplifies the firm's negative performance. For example, this amplification of the negative results occurs when the firm chases lowest costs from supplier to supplier with a possible reduction in product quality.

In contrast to the positive subsample, the coefficient associated with the low Altman's Z is significant at the $10 \%$ level, indicating that the firm is a potential candidate for bankruptcy proceedings. This is an expected result for firms in potential financial distress that are laying off workers. The negative and positive subsample results are substantively different with the exception of the coefficient of technological intensity having significant explanatory powers for both, but in opposite directions.

\subsection{Human Capital Reductions and Coincident Exogenous Events: Full Sample, Positive and Negative Subsample Results}

\subsubsection{Total Sample Results for Macroeconomic Events}

Table 6 provides the results for the coincident exogenous events and human capital reductions. Figure 2 in section 3.3 depicts these exogenous macroeconomic events and potential interaction effects between them, which occur during the sample period. These macroeconomic time-periods, which are coincident to a human capital layoff, job cut or early retirement event, seem to have no impact on the market returns for the total sample. ${ }^{40}$ Only size and the intercept are statistically significant. However, as before, when we split the sample into negative and positive market response subsamples, exogenous macroeconomic time-periods have significant explanatory power.

\subsubsection{Positive Returns Subsample Results for Macroeconomic Events}

For the positive returns subsample, it is noteworthy that four regression coefficients (size, dotcom, lagged employment and an interaction term) are statistically significant and the intercept is no longer so. The Chi-Square statistic is significant at greater than the $1 \%$ level.

\footnotetext{
${ }^{40} \mathrm{We}$ also examined the impact of increasing international competition by examining the percent change in international trade for the period 1997 to 2010. We had to truncate the sample since the data were available only after January 1996. We did find some impacts of this variable on the positive CARs subsample at the $10 \%$ level of significance. Those results are available from the authors.
} 
Size, dotcom and lagged employment reinforce the positive market returns due to the announcement of a layoff. The interaction term associated with manufacturing outsourcing, white-collar outsourcing, and cold war dampen the impact of the market reaction. Inferentially, size and two macroeconomic events significantly explain the positive response to human capital reductions, indicating that upturns in the business cycle for technologically intensive firms may be generally associated with a favorable market response to corporate downsizing and is exactly what the successful financial management of a firm should normatively do.

Table 6. Human Capital Reductions: Market reaction based on Macroeconomic Events

\begin{tabular}{|c|c|c|c|c|c|c|}
\hline \multirow{2}{*}{ Hypothesis } & \multicolumn{2}{|c|}{$\begin{array}{c}\text { Total Sample w/ } \\
\text { Exogenous Events }\end{array}$} & \multicolumn{2}{|c|}{$\begin{array}{l}\text { Positive Sample w/ } \\
\text { Exogenous Events }\end{array}$} & \multicolumn{2}{|c|}{$\begin{array}{l}\text { Negative Sample w/ } \\
\text { Exogenous Events }\end{array}$} \\
\hline & $\begin{array}{l}\text { Coefficient } \\
\text { (t-statistic) }\end{array}$ & $P>|t|$ & $\begin{array}{l}\text { Coefficient } \\
\text { (t-statistic) } \\
\end{array}$ & $P>|t|$ & $\begin{array}{l}\text { Coefficient } \\
\text { (t-statistic) }\end{array}$ & $P>|t|$ \\
\hline Size (natural log of assets) & $\begin{array}{c}0.00261^{* * *} \\
(2.67) \\
\end{array}$ & 0.008 & $\begin{array}{c}-0.00432^{* * * *} \\
(-3.90) \\
\end{array}$ & 0.000 & $\begin{array}{c}0.00729 * * * \\
(6.99) \\
\end{array}$ & 0.000 \\
\hline Cold War Dividend & $\begin{array}{c}0.01530 \\
(0.85) \\
\end{array}$ & 0.394 & $\begin{array}{c}-0.00174 \\
(-0.09) \\
\end{array}$ & 0.929 & $\begin{array}{c}0.00226 \\
(0.11) \\
\end{array}$ & 0.912 \\
\hline Manufacturing Outsourcing & $\begin{array}{c}-0.01178 \\
(-1.04) \\
\end{array}$ & 0.301 & $\begin{array}{c}0.01292 \\
(1.12) \\
\end{array}$ & 0.263 & $\begin{array}{c}-0.01250 \\
(-0.90) \\
\end{array}$ & 0.370 \\
\hline Dotcom & $\begin{array}{c}0.00239 \\
(0.48)\end{array}$ & 0.630 & $\begin{array}{c}0.01099 * * \\
(1.99)\end{array}$ & 0.047 & $\begin{array}{c}-0.00979^{*} \\
(-1.82)\end{array}$ & 0.069 \\
\hline White Collar Outsourcing & $\begin{array}{c}-0.00520 \\
(-0.45)\end{array}$ & 0.625 & $\begin{array}{c}0.01889 \\
(0.34)\end{array}$ & 0.180 & $\begin{array}{c}-0.02115^{*} \\
(1.83)\end{array}$ & 0.068 \\
\hline Savings and Loan Crisis & $\begin{array}{c}0.01574 \\
(1.22)\end{array}$ & 0.223 & $\begin{array}{c}-0.00211 \\
(-0.15)\end{array}$ & 0.879 & $\begin{array}{c}0.00822 \\
(0.54)\end{array}$ & 0.589 \\
\hline Subprime Housing Crisis & $\begin{array}{c}0.00664 \\
(0.96)\end{array}$ & 0.338 & $\begin{array}{c}0.00374 \\
(0.47)\end{array}$ & 0.639 & $\begin{array}{c}0.00169 \\
(0.23)\end{array}$ & 0.817 \\
\hline $\begin{array}{l}\text { Lagged } \\
\text { Employment }\end{array}$ & $\begin{array}{c}0.06219 \\
(0.30)\end{array}$ & 0.765 & $\begin{array}{c}0.44633^{*} \\
(1.86)\end{array}$ & 0.064 & $\begin{array}{c}-0.26174 \\
(-1.20)\end{array}$ & 0.232 \\
\hline $\begin{array}{l}\text { Interaction one: Manufacturing } \\
\text { outsourcing-cold war-dotcom-white collar } \\
\text { outsourcing }\end{array}$ & $\begin{array}{c}0.00469 \\
(0.32)\end{array}$ & 0.750 & $\begin{array}{c}-0.02801^{*} \\
(-1.65)\end{array}$ & 0.100 & $\begin{array}{c}0.03152^{* *} \\
(2.03)\end{array}$ & 0.043 \\
\hline $\begin{array}{l}\text { Interaction two: Manufacturing } \\
\text { outsourcing-cold war-S\&L crisis }\end{array}$ & $\begin{array}{c}-0.01345 \\
(-0.80)\end{array}$ & 0.423 & $\begin{array}{c}-0.00875 \\
(-0.48)\end{array}$ & 0.629 & $\begin{array}{c}0.00699 \\
(0.36)\end{array}$ & 0.718 \\
\hline Intercept & $\begin{array}{c}-0.0350^{*} \\
(-1.65)\end{array}$ & 0.099 & $\begin{array}{c}0.03183 \\
(1.27)\end{array}$ & 0.206 & $\begin{array}{c}-0.07468 * * * \\
(-3.42) \\
\end{array}$ & 0.001 \\
\hline Number of Observations & \multicolumn{2}{|c|}{1561} & \multicolumn{2}{|c|}{712} & \multicolumn{2}{|c|}{849} \\
\hline F-Statistic $(10,1550)$ & \multicolumn{2}{|c|}{1.09} & \multicolumn{2}{|l|}{-} & \multicolumn{2}{|l|}{-} \\
\hline Probability > F & \multicolumn{2}{|c|}{0.3658} & \multicolumn{2}{|l|}{-} & \multicolumn{2}{|l|}{-} \\
\hline LR Chi Square (10) & \multicolumn{2}{|c|}{-} & \multicolumn{2}{|c|}{40.08} & \multicolumn{2}{|c|}{80.02} \\
\hline Probability > Chi-Squared & \multicolumn{2}{|c|}{-} & \multicolumn{2}{|c|}{0.000} & \multicolumn{2}{|c|}{0.000} \\
\hline Adjusted $\mathrm{R}^{2}$ & \multicolumn{2}{|c|}{0.0006} & \multicolumn{2}{|l|}{ - } & \multicolumn{2}{|l|}{-} \\
\hline
\end{tabular}

In Table 6, we present evidence of regressions of the cumulative abnormal returns against various exogenous events for the total sample and positive and negative subsamples. Data for inclusion in this table come from firms with multiple work force reductions that are a minimum of six months apart and the news reporting did not indicate that this reduction was the next step in an on-going layoff plan. We show results for $t=(-1$ to +1$)$. Results for $\mathrm{t}=(0$ to +1$)$ and $\mathrm{t}=(-5$ to +5$)$ are directionally the same but with lower explanatory power. We use the firm's total assets as a proxy for firm size. (Note we also use firm sales as a proxy for firm size and achieve similar results). Each model considers abnormal returns based on value weighted (VW) market returns. (Results 
based on equally weighted returns and those in the alternative event windows are available from the authors). t-statistics are in parentheses below the parameter estimates. For the total sample, we use ordinary least squares and for the truncated positive and negative subsamples, we use a Tobit regression from STATA® to estimate the parameters. \$ Number of observations is dependent on the availability of CRSP and Compustat data. $*$ significant at $10 \%, * *$ significant at $5 \%, * * *$ significant at $1 \%$.

\subsubsection{Negative Returns Subsample Results for Macroeconomic Events}

The coefficients on the dotcom and white-collar outsourcing are negative and reinforce the negative impacts of a corporate downsizing; whereas, size and the interaction effect of manufacturing outsourcing and the cold war are positive and offset the negative impact of the layoff. For the negative market response subsample, size, dotcom, white-collar outsourcing and an interaction term are statistically significant and the overall Chi-squared statistic is significant at the better than the $1 \%$ level. However, the negative intercept is also significant at the $1 \%$ level, which indicates unlike the positive subsample that for the negative subsample we are still missing one or more explanatory variables.

\subsection{Moderator and Mediator Robustness Analysis of Total Sample Results}

We report the results in Table 7 of step 3 of the Barron and Kenny (1986) analytical process. ${ }^{41}$ We employ the Barron and Kenny (1986) process using a stepwise regression methodology. The mediator / moderator variable we select, idiosyncratic risk, does contribute explanatory power, increasing the F-statistic for the regression models. We obtained the similar results with the mediator and moderator variables as in Table 5 and Table 6.

Table 7 reinforces the explanatory power of low Altman's Z, technological intensity, technological change, offshoring and the moderator variable (private risk). ${ }^{42}$ Interestingly, idiosyncratic risk does not enter our model as a standalone variable in our stepwise regression. Only when we use it as a mediator or moderator variable as a cross product term with other variables does it contribute explanatory power. When we include firm attributes, firm decisions and economic variables, the macroeconomic variables are again statistically insignificant at the total sample level. This result reinforces our decision to split the sample into positive and negative subsamples. Adding the moderator/mediator variable added explanatory power, but did not eliminate the diversity in the empirical results of previous literature or in our findings. It appears that markets react differently to firms laying off human capital depending on the firm's attributes, decisions and the economic environment. Clearly, there are two types of categories of firms and economic conditions that generate the differing empirical results in our research and that of others.

\footnotetext{
41 We thank an anonymous referee for suggesting the use of this technique. The results of steps 1 and 2 of the Barron and Kenny (1986) analytical process are available from the authors.

${ }^{42}$ We note that size continues to be significant as is well established in the literature.
} 
Table 7. Stepwise Regression Results using Moderator/Mediator Variables

\begin{tabular}{|c|c|c|c|c|c|c|}
\hline & Step (1) & Step (2) & Step (3) & Step (4) & Step (5) & Step (6) \\
\hline \multicolumn{7}{|l|}{ Mediator (ME) } \\
\hline $\begin{array}{l}\text { Size (natural log of } \\
\text { assets) }\end{array}$ & & $\begin{array}{c}0.00320 * * \\
(5.98) \\
0.0146 \\
\end{array}$ & $\begin{array}{c}0.00365 * * * \\
(7.56) \\
0.0060 \\
\end{array}$ & $\begin{array}{c}0.00365^{* * *} \\
(7.56) \\
0.0060 \\
\end{array}$ & $\begin{array}{c}0.00356^{* * *} \\
(7.18) \\
0.0075 \\
\end{array}$ & $\begin{array}{c}0.00316^{* *} \\
(5.50) \\
0.0192 \\
\end{array}$ \\
\hline $\begin{array}{l}\text { Low Altman's Z * } \\
\text { ME }\end{array}$ & $\begin{array}{c}-0.00760 * * * \\
(28.20) \\
<0.0001 \\
\end{array}$ & $\begin{array}{c}-0.00743^{* * * *} \\
(26.99) \\
<0.0001\end{array}$ & $\begin{array}{c}-0.00739 * * * \\
(26.75) \\
<0.0001\end{array}$ & $\begin{array}{c}-0.00820 * * * \\
(30.19) \\
<0.0001 \\
\end{array}$ & $\begin{array}{c}-0.00533 * * \\
(5.65) \\
0.0176\end{array}$ & $\begin{array}{c}-0.00527 * * \\
(5.54) \\
0.0187\end{array}$ \\
\hline Tech Intensity $*$ ME & & & & & $\begin{array}{c}-0.00492 * \\
(2.97) \\
0.0853 \\
\end{array}$ & $\begin{array}{c}-0.00511 * \\
(3.20) \\
0.0739 \\
\end{array}$ \\
\hline $\begin{array}{l}\text { Asset Change } \\
\text { Announcement }\end{array}$ & & & & & & $\begin{array}{c}0.00700^{*} \\
(2.83) \\
0.0927 \\
\end{array}$ \\
\hline $\begin{array}{l}\text { Offshoring } \\
\text { Announcement }\end{array}$ & & & $\begin{array}{c}-0.00848^{*} \\
(3.64) \\
0.0565 \\
\end{array}$ & $\begin{array}{c}-0.00849^{*} \\
(3.66) \\
0.0559 \\
\end{array}$ & $\begin{array}{c}-0.00807 * \\
(3.31) \\
0.0693 \\
\end{array}$ & $\begin{array}{c}-0.00858^{*} \\
(3.73) \\
0.0538 \\
\end{array}$ \\
\hline $\begin{array}{l}\text { Asset } \\
\text { Change*Tech*ME }\end{array}$ & & & & $\begin{array}{c}0.00741^{*} \\
(3.45) \\
0.0634 \\
\end{array}$ & $\begin{array}{c}0.00807^{* *} \\
(4.06) \\
0.0441 \\
\end{array}$ & $\begin{array}{c}0.00796 * * \\
(3.96) \\
0.0468 \\
\end{array}$ \\
\hline Intercept & $\begin{array}{c}-0.0039 * * \\
(4.38) \\
0.0366 \\
\end{array}$ & $\begin{array}{c}-0.03155^{* * *} \\
(7.58) \\
0.0060 \\
\end{array}$ & $\begin{array}{c}-0.02894 * * \\
(6.30) \\
0.0122 \\
\end{array}$ & $\begin{array}{c}-0.02886^{* * *} \\
(6.28) \\
0.0124 \\
\end{array}$ & $\begin{array}{c}-0.02844 * * \\
(6.10) \\
0.0136 \\
\end{array}$ & $\begin{array}{c}-0.02965^{* *} \\
(6.62) \\
0.0102 \\
\end{array}$ \\
\hline $\begin{array}{l}\text { Number of } \\
\text { observations }\end{array}$ & 1263 & 1263 & 1263 & 1263 & 1263 & 1263 \\
\hline F-statistic & 28.2 & 17.14 & 12.67 & 10.38 & 8.91 & 7.91 \\
\hline Probability $>$ F & $<0.0001$ & $<0.0001$ & $<0.0001$ & $<0.0001$ & $<0.0001$ & $<0.0001$ \\
\hline R-squared & 0.0219 & 0.0265 & 0.0293 & 0.0302 & 0.0342 & 0.0364 \\
\hline Adjusted R-squared & 0.0211 & 0.0249 & 0.0269 & 0.0288 & 0.0303 & 0.0317 \\
\hline
\end{tabular}

In Table 7, we present evidence of regressions of the cumulative abnormal returns against various exogenous events, firm attributes and decisions for the total sample using stepwise regression. We add all variables in equations 1.1 and 1.2 in a stepwise fashion. We use the $10 \%$ level of significance as a cutoff to determine which variables are significant and remain in the regression. Data for inclusion in this table come from firms with multiple work force reductions that are a minimum of six months apart and the news reporting did not indicate that this reduction was the next step in an on-going layoff plan. We show results for $t=(-1$ to +1$)$. We use the firm's total assets as a proxy for firm size. Each model considers abnormal returns based on value weighted (VW) market returns-statistics are in parentheses below the parameter estimates. $\$$ Number of observations is dependent on the availability of CRSP and Compustat data. * Significant at $10 \%, * *$ significant at $5 \%$, *** significant at $1 \%$.

\section{Discussion}

We examine human capital restructurings, layoffs, job cuts and early retirement announcements from 1980 to 2010. In this time-period, there are well over 100,000 such announcements. In order to create a manageable sample for analysis, the S\&P 400, S\&P 500, and S\&P 600 are used. In this time-period, there are 2762 firms (current and deleted) in the indices but only 385 firms with a total of 1758 human capital reduction announcements. The 385 firms represent $13.9 \%$ of the total firms in the indices. Of those 385 firms, 87 (23\%) firms have single announcements and $298(77 \%)$ have multiple announcements for a ratio of 
3 to 1 ; however, for the $\mathrm{S} \& \mathrm{P} 500$ the ratio of multiple to single announcements is approximately 9 to 1 . The 385 sample firms with human capital reductions also make other announcements within six months on either side of the human capital downsizing announcement date: asset change announcements (64.7\%), financial change announcements (30.9\%), technology change announcements (4.4\%), and offshoring announcements $(53.8 \%)$. The number of employees impacted is not proportional to the number of announcements with peak human capital changes occurring around major changes in the business cycle. There are four peaks during the examination period: 1) the 2007 to 2009 great recession; 2) the 2001 to 2002 dotcom boom and bust period; 3) the 1998 to 1999 recession and 4) the 1991 to 1992 recession.

Overall, the market response to the human capital announcements is statistically negative and is consistent with previous literature. However, the number of firms with positive and negative announcement responses in our sample is approximately $45 / 55$ percent. This is consistent with some previous literature, which documents a positive market response. Our contribution is the examination of firm attributes, firm decisions and external macroeconomic events with an eye to inferentially determining their impacts on the differing market responses for the total sample and the two subsamples (See Table 8).

Not surprisingly, we find that size matters with only the firms in the S\&P 600 lacking a statistically significant result. This may be a function of less media coverage for these smaller firms. Our evidence indicates that bankruptcy risk and potential, offshoring and simultaneous asset change announcements are associated with the overall negative market response. Exogenous factors do not seem to play a role in the total sample market returns, but do influence the two subsamples.

When considering the subsample with positive market responses to the human capital announcement, not surprisingly, bankruptcy potential is not a significant influence. However, technological intensity and simultaneous asset change announcements (at the 10\% level) do affect the positive market response, making it more positive. Considering exogenous influences on the positive market returns subsample, the Dotcom period and business cycle (lagged employment at the $10 \%$ level) reinforce the positive market response. A positive movement in the business cycle and the commercialization of the internet seem correctly associated with positive market returns for downsizing events for this subsample. The complex interaction of exogenous influences in the economy creates uncertainty and the negative coefficient associated with these exogenous interaction effects for the positive market returns subsample seems reasonable and consistent with naïve expectations. In periods of significant macro-economic uncertainty, managers may face challenges making value-maximizing decisions. 
Table 8. Summary of Results of the Analysis

\begin{tabular}{|c|c|c|c|c|}
\hline \multirow{2}{*}{$\begin{array}{l}\text { Hypothesis } \\
\text { Number }\end{array}$} & \multirow{2}{*}{$\begin{array}{l}\text { Null Hypotheses Regarding Human Capital } \\
\text { Announcements: Firm Attributes and Decisions }\end{array}$} & \multicolumn{3}{|c|}{ Not Reject (NR) or Reject (R) the Null Hypothesis } \\
\hline & & $\begin{array}{r}\text { Total } \\
\text { Sample } \\
\end{array}$ & $\begin{array}{c}\text { Positive Sub } \\
\text { sample }\end{array}$ & $\begin{array}{c}\text { Negative Sub } \\
\text { sample }\end{array}$ \\
\hline 1 & Size of firm has no impact & $\boldsymbol{R}$ & $\boldsymbol{R}$ & $\boldsymbol{R}$ \\
\hline 2 & Bankruptcy potential has no impact & $\boldsymbol{R}$ & NR & $\boldsymbol{R}$ \\
\hline 3 & Technological intensity has no impact & NR & $\boldsymbol{R}$ & $\boldsymbol{R}$ \\
\hline 4 & Announcement of asset change has no impact & $\boldsymbol{R}$ & $\boldsymbol{R}$ & NR \\
\hline 5 & Announcement of financing change has no impact & NR & NR & NR \\
\hline 6 & Announcement of focus change has no impact & $\mathrm{NE}$ & $\mathrm{NE}$ & $\mathrm{NE}$ \\
\hline 7 & Announcement of offshoring decision has no impact & $\boldsymbol{R}$ & NR & $\boldsymbol{R}$ \\
\hline 8 & Announcement of technological change has no impact & NR & NR & NR \\
\hline 9 & The cold war peace dividend has no impact & NR & NR & NR \\
\hline 10 & White collar outsourcing has no impact & NR & NR & $\boldsymbol{R}$ \\
\hline 11 & Manufacturing outsourcing has no impact & NR & NR & NR \\
\hline 12 & Dotcom has no impact & NR & $\boldsymbol{R}$ & $\boldsymbol{R}$ \\
\hline 13 & The savings and loan collapse has no impact & NR & NR & NR \\
\hline 14 & The subprime mortgage collapse has no impact & NR & NR & NR \\
\hline 15 & Macroeconomic employment growth has no impact & NR & $\boldsymbol{R}$ & NR \\
\hline 16 & Growth in foreign competition has no impact & NE & NE & NE \\
\hline 17 & Change in government regulation has no impact & $\mathrm{NE}$ & NE & $\mathrm{NE}$ \\
\hline \multirow[t]{6}{*}{18} & Various interaction effects have no impact & - & - & - \\
\hline & $\begin{array}{l}\text { Manufacturing outsourcing-cold war-dotcom-white } \\
\text { collar outsourcing }\end{array}$ & NR & $\boldsymbol{R}$ & $\boldsymbol{R}$ \\
\hline & Manufacturing outsourcing-cold war-S\&L crisis & NR & NR & NR \\
\hline & Asset -finance interaction term has no impact & NR & NR & NR \\
\hline & Asset-tech change interaction term has no impact & NR & NR & NR \\
\hline & Tech intensity-tech change interaction has no impact & NR & NR & NR \\
\hline
\end{tabular}

$\mathrm{NE}=$ No evidence since the variable was dropped due to multicollinearity

In contrast, when we consider the negative market response subsample, the exogenous event of the Dotcom period is statistically significant but has an opposite sign from that in the positive market returns subsample. The market views the actions of the firm in decreasing its workforce negatively perhaps out of concern that the firm may not recover well when the opportunity to do so arises and the economy improves. Consistent with some views expressed in the popular media, expectedly bankruptcy risk is statistically significant for the negative market returns subsample. Technological intensity and offshoring for the negative subsample are also significant, but in the opposite direction of the positive subsample, consistent with the above interpretation that recovery for these downsizing firms may be more challenging in future periods.

\section{Summary and Conclusions}

Overall, our evidence suggests that human capital reductions occur frequently and that most firms engage in them on more than one occasion. Like others, our results suggest an average negative market response. However, the average response is not necessarily the actual response for a specific individual firm. Approximately forty-five percent of our sample experiences a positive market reaction to the announcement of the downsizing event. The investment market response to a human capital downsizing event is firm specific. Firm 
characteristics, firm decisions and certain external macroeconomic conditions influence that market reaction.

For firms responding positively to the downsizing event, the firm's technological intensity and simultaneous asset reorganization seem to be significant contributors. Significant factors for firms responding negatively include potential financial distress and offshoring. Technological intensity is also a significant influence, but is different for the two subsamples. For positive responding firms, the market may perceive that the firm is pro-actively managing its costs well. For the negative responding firms, the market may perceive that knowledge workers may not be available when and if the firm recovers. Our conjecture concerning technology intensive and downsizing events requires further study.

Exogenous events also influence the market responses to downsizing events differentially. External market conditions positively influence firms whose share price increase because of human capital downsizing. While those that respond negatively seem to be negatively influenced by external market conditions. This suggests that management should carefully examine both external market conditions as well as relevant firm attributes before deciding whether to announce a layoff. Our research provides some initial pragmatic suggestions for management as they consider their cost structures and their human resource capital budgeting decisions. Interesting areas for future research involve a focus on the firm characteristics that seem to be the most influential, technological change and technological intensity. In the longer term, a specific model suggesting how an executive or manager might consider the findings to develop an approach for his/her specific firm would be a reasonable research extension.

\section{References}

Agrawal, V., \& Farrell, D. (2003). Who wins in Offshoring. McKinsey Quarterly, Special Addition, 36-53.

Agrawal, A., Jaffe, J. F., \& Mandelker, J. M. (April 1999). The Post- Merger Performance of Acquiring Firms: A Re-Examination of an Anomaly. Journal of Finance, 47, 1605-1622. https://doi.org/10.1111/j.1540-6261.1992.tb04674.x

Aharony, J., Jones, C., \& Swary, I. (1980). An analysis of risk and return characteristics of corporate bankruptcy using capital market data. Journal of Finance, 35, 1001-1016. https://doi.org/10.1111/j.1540-6261.1980.tb03516.x.

Ashbaugh-Skaife, H., Collins, D. W., Kinney, W. R., \& Lanford, R. (2009). The Effect of SOX Internal Control Deficiencies on Firm Risk and Cost of Equity. Journal of Accounting Research, 47(1), 1-43. https://doi.org/10.1111/j.1475-679X.2008.00315.x.

Allen, J. W., \& McConnell, J. J. (1998). Equity Carve-Outs and Managerial Discretion. Journal of Finance, 53,163-186. https://doi.org/10.1111/0022-1082.65022.

Altman, E. (1968). Financial Ratios, Discriminant Analysis \& the Prediction of Corporate Bankruptcy. Journal of Finance, 23, 189-209.

http://dx.doi.org/10.1111/j.1540-6261.1968.tb00843.x. 
Altman, E. (1984). A Further Investigation of the Bankruptcy Cost Question. Journal of Finance, 39, 1067-1089. http://dx.doi.org/10.2307/2327613.

Altman, E. (2014a). Revisiting the Recidivism -- Chapter 22 Phenomenon in the U.S. Bankruptcy System. Brooklyn Journal of Corporate, Financial \& Commercial Law, 8 Brook. J. Corp. Fin. \& Com. L. 253.

Altman, E. (2014b). Revisiting the Recidivism - Chapter 22 Phenomenon in the U.S. Bankruptcy System. Keynote Speech at the Eastern Finance Association Annual Meeting in Pittsburgh, PA. April 9 - 12, 2014.

Anderson, A., Cowan, E. J., \& Denning, K. (2015). Human Capital Reorganizations and Market Performance: U.S. Firms. Business and Economic Research, 5(2), 97-121. https://doi.org/10.5296/ber.v5i2.7878.

Baldwin, C., \& Kim, S. (2010). GM IPO raises \$20.1 Billion. Reuters, Available: http://www.reuters.com/article/2010/11/17/us-gm-ipo-idUSTRE6AB43H20101117 (June 18, 2013).

Bardhan, A., \& Kroll, C. (2003). The New Wave of Outsourcing. Fisher Center for Real Estate \& Urban Economics Research Report, 1103. https://doi.org/10.2139/ssrn.985741.

Baron, R. M., \& Kenny, D. A. (1986). The moderator-mediator variable distinction in social psychological research: Conceptual, strategic, and statistical considerations. Journal of Personality and Social Psychology, 5(6), 1173-1182.

https://doi.org/10.1037/0022-3514.51.6.1173.

Blinder, A. (2006). Offshoring the next Industrial Revolution? Foreign Affairs, 1 Mar 2006, Available:

http://www.foreignaffairs.com/articles/61514/alan-s-blinder/offshoring-the-next-industrial-re volution (June 14, 2014).

BLS (2014). Monthly Unemployment Rates. U.S. Bureau of Labor Statistics.

Boyd, J., Hu J., \& Jagannathan R. (2005). The Stock Market's Reaction to Unemployment News: Why Bad News Is Usually Good for Stocks. Journal of Finance, 60, 649-672. https://doi.org/10.1111/j.1540-6261.2005.00742.x.

Bradley, M., Dsai, A., \& Kim, E. H. (April 1983). The Rationale behind Interfirm Tender Offers: Information or Synergy. Journal of Financial Economics, 11(1), 3-40. https://doi.org/10.1016/0304-405X(83)90010-7.

Brookman, J., Chang S., \& Rennie, C. (2007a). CEO cash and stock-based compensation changes, layoff decisions, and shareholder value. Financial Review, 42, 99-119.

http://dx.doi.org/10.1111/j.1540-6288.2007.00163.x.

Brookman, J., Chang, S., \& Rennie, C. (2007b). CEO equity portfolio incentives and layoff decisions. Journal of Financial Research, 30, 259-81.

http://dx.doi.org/10.1111/j.1475-6803.2007.00213.x. 


\section{Al Macrothink}

Business and Economic Research ISSN 2162-4860 2018, Vol. 8, No. 1

Brown, S., \& Warner, J. (1985). Using Daily Stock Returns: The Case of Event Studies. Journal of Financial Economics, 14, 3-31. http://dx.doi.org/10.1016/0304-405X(85)90042-X.

Chen, P., Mehrotra, V., Sivakumar, R., \& Yu, W. (2001). Layoffs, shareholders' wealth and corporate performance. Journal of Empirical Finance, 8, 171-99.

http://dx.doi.org/10.1016/S0927-5398 (01)00024-X.

Chichernea, D. C., Ferguson, M. F. and Kassa, H. (2015). Idiosyncratic Risk, Investor Base, and Returns. Financial Management, 44(2), 267-293. http://dx.doi.org/10.1111/fima.12067.

Constantinides, G., \& Grundy, B. (1989). Optimal Investment with Stock Repurchase and Financing as Signals. Review of Financial Studies, 2, 445-465.

https://doi.org/10.1093/rfs/2.4.445.

Copeland, T. E., \& Lee, W. H. (August 1991). Exchange Offers and Stock Swaps: Some New Evidence. Financial Management, 34-48. https://doi.org/10.2307/3665749.

Couper, E. A., Hejkal, J. P., \& Wolman, A. L. (2003). Boom and Bust in Telecommunications. Federal Reserve Bank of Richmond Economic Quarterly Volume, 89(4), 1-24.

Daley, L., Mehrotra, V., \& Sivakumar, R. (1997). Corporate Focus and Value Creation: Evidence from Spinoffs. Journal of Financial Economics, 45, 257-281.

https://doi.org/10.1016/S0304-405X(97)00018-4.

Dann, L., \& Mikkelson, W. (June 1984). Convertible Debt Issuance, Capital Structure Change and Financing-Related Information: Some New Evidence. Journal of Financial Economics, 157-186. https://doi.org/10.1016/0304-405X(84)90022-9.

De La Merced, M. (2012). Eastman Kodak Files for Bankruptcy, New York Times, Available: http://dealbook.nytimes.com/2012/01/19/eastman-kodak-files-for-bankruptcy (June 13, 2013).

Denning, K., \& Shastri, K. (2011). Human Capital Restructuring and Firm Performance: Are Operating Objectives Achieved? Journal of Current Issues in Finance, Business and Economics, 4, 207-220.

Denning, K. C., Hulburt, H., \& Ferris, S. P. (2006). Risk and wealth effects of U.S. firm joint venture activity. Review of Financial Economics, 15(3), 271-285.

https://doi.org/10.1016/j.rfe.2005.08.003.

Derrien, F., \& Kecskes, A. (2013). The Real Effects of Financial Shocks: Evidence from Exogenous Changes in Analyst Coverage. The Journal of Finance, 68, 1407-1440.

https://doi:10.1111/jofi.12042.

Desai, H., \& Jain, P. C. (1999). Firm Performance and Focus: Long-Run Stock Performance Following Spinoffs. Journal of Financial Economics, 54, 75-101.

https://doi.org/10.1016/S0304-405X(99)00032-X.

Dossani, R., \& Kenney, M. (2003). Lift and Shift: Moving the back office to India. The Massachusetts Institute of Technology Information Technologies and International 
Development, 1, 21-37. https://doi.org/10.1162/154475203322981941.

Du, D., Denning, K., \& Zhao, X. (2012). Real Aggregate Activity and Stock Returns. Journal of Economics and Business, 64, 323- 337. https://doi.org/10.1016/j.jeconbus.2012.06.002.

Dyer, J. H., Kale, P., \& Singh, H. (2001). How to Make Strategic Alliances Work. MIT Sloan Management Review, 42, 37-43.

Elayan, F., Swales, G., Maris, B., \& Scott, J. (1998). Market reactions, characteristics, and the effectiveness of corporate layoffs. Journal of Business, Finance, and Accounting, 25, 329-51. https://doi.org/10.1111/1468-5957.00190.

Fang, L. H., and Peress, J. (2009). Media Coverage and the Cross-Section of Stock Returns. The Journal of Finance, 64(5), 2023-2052. https://doi.org/10.1111/j.1540-6261.2009.01493.x.

Farber, H., \& Hallock, K. (2009). The changing relationship between job loss announcements and stock prices: 1970-1999. Labour Economics, 16, 1-11.

http://dx.doi.org/10.1016/j.labeco.2008.04.002.

Flannery, M., \& Protopapadakis, A. (2002). Macroeconomic Factors Do Influence Aggregate Stock Returns. Review of Financial Studies, 15, 751-782.

https://doi.org/10.1093/rfs/15.3.751.

Franks, J., Harris, R., \& Titman, S. (1991). The Postmerger Share-Price Performance of Acquiring Firms. Journal of Financial Economics, Journal of Financial Economics, 29, 81-96. https://doi.org/10.1016/0304-405X(91)90014-B.

Gaddis, J. L. (2005). The Cold War: A New History. New York: Penguin Press.

Hallock, K. (1998). Layoffs, top executive pay, and firm performance. American Economic Review, 88, 711-23.

Hardouvelis, G. A. (1987). Macroeconomic Information and Stock Prices. Journal of Economics and Business, 39, 131-140. https://doi.org/10.1016/0148-6195(87)90012-9.

Herskovic, B., Kelly, B. T., Lustig, H. N. and Van Nieuwerburgh, S. (2016). The common Factor in idiosyncratic volatility: Quantitative asset pricing implications. Journal of Financial Economics, 119(2), 249-283. https://doi.org/10.1016/j.jfineco.2015.09.010.

Hong, H., Lim, T., \& Stein, J. C. (2000). Bad News Travels Slowly: Size, Analyst Coverage, and the Profitability of Momentum Strategies. The Journal of Finance, 55, 265-295. https://doi:10.1111/0022-1082.00206.

Ikenberry, D., Lakonishok, J., \& Vermaelen, T. (1995). Market Underreaction to Open Market Share Repurchases. Journal of Financial Economics, 39, 181-208.

https://doi.org/10.1016/0304-405X(95)00826-Z.

John, K., Lang, L., \& Netter, J. (1992). The Voluntary Restructuring of Large Firms in Response to Performance Decline. The Journal of Finance, 47, 891-917. 
http://dx.doi.org/10.2307/2328971.

Kaplan, S., \& Weisbach, M. S. (1992). The Success of Acquisitions: Evidence from Divestitures. Journal of Finance, 47, 107-138.

https://doi.org/10.1111/j.1540-6261.1992.tb03980.x.

Keasler, T., \& Denning, K. (2009). A Re-examination of Corporate Strategic Alliances: New Market Responses. (Formerly Quarterly Journal of Business and Economics), Quarterly Journal of Finance and Accounting, 48(1), 21-47.

Kneale, K. (2009). January 2009 Layoffs. Layoffs for January 2009 at America's 500 largest public companies: 163,662. Forbes, Available:

http://www.forbes.com/2009/01/09/january-layoffs-fires-lead-cx_kk_0109january09layoffs.ht $\mathrm{ml}$ (January 8, 2016).

Lakonishok, J., \& Vermaelen, T. (1990). Anomalous Price Behavior around Repurchase Tender Offers. Journal of Finance, 45, 455-477.

https://doi.org/10.1111/j.1540-6261.1990.tb03698.x.

Lakonishok, J., \& Vermaelen, T. (1995). Market Underreaction to Open Market Share Repurchases. Journal of Financial Economics, 39, 181-208.

https://doi.org/10.1016/0304-405X(95)00826-Z.

Lin, J-C., \& Rozeff, M. S. (1993). Capital Market Behavior and Operational Announcements of Layoffs, Operation Closings, and Pay Cuts. Review of Quantitative Finance and Accounting, 3, 29-45. https://doi.org/10.1007/BF02408411.

Marshall, A., McColgan, P., \& McLeish, S. (2012). Why do stock prices decline in response to employee layoffs? UK evidence from the 2008 global financial crisis. Journal of Financial Research, 35, 375-396. https://doi.org/10.1111/j.1475-6803.2012.01321.x.

Masulis, R. (June 1980). The Effects of Capital Structure Change on Security Prices: A study of Exchange Offers. Journal of Financial Economics, 139-178.

https://doi.org/10.1016/0304-405X(80)90015-X.

McConnell, J. J., \& Nantell, T. J. (1985). Corporate Combinations and Common Stock Returns: The Case of Joint Ventures. Journal of Finance, 40, 519-536.

https://doi.org/10.1111/j.1540-6261.1985.tb04970.x.

McDonald, J. F., \& Moffitt, R. A. (1980). The Uses of Tobit Analysis. The Review of Economics and Statistics, 62(2), 318-321. https://doi.org/10.2307/1924766.

McQueen, G., \& Roley, V. (1993). Stock Prices, News, and Business Conditions. Review of Financial Studies, 6, 683-707. https://doi.org/10.1093/rfs/5.3.683.

Mincer, J. (1989). Human Capital Responses to Technological Changes in the Labor Market. National Bureau of Economic Research, Working paper number W3207.

Meucci, A. (2014). Linear Factor Models: Theory, Applications and Pitfalls. Available at SSRN: https://ssrn.com/abstract=1635495 or http://dx.doi.org/10.2139/ssrn.1635495. 


\section{Macrothink}

Business and Economic Research ISSN 2162-4860 2018, Vol. 8, No. 1

North American Industry Classification System (1996-2012). U.S. Census.

Palmon, O., Sun, H., \& Tang, A. (1997). Layoff announcements: stock market impact and financial performance. Financial Management, 26(3), 54-68.

https://doi.org/10.2307/3666213.

Paytas, J., \& Berglund, D. (2004). Technology Industries and Occupations for NAICS Industry Data. State Science and Technology Institute, 1-7.

Pearce, D. K., \& Roley, V. V. (1983). The Reaction of Stock Prices to Unanticipated Changes in Money: A Note. Journal of Finance, 38, 1323-1333.

https://doi.org/10.1111/j.1540-6261.1983.tb02303.x.

Poitras, M. (2004). The Impact of Macroeconomic Announcements on Stock Prices: In Search of State Dependence. Southern Economic Journal, 70, 549-565.

https://doi.org/10.2307/4135330.

Roll, R. (1983). The Turn-of-the-Year Effect and the Return Premia of Small Firms. Journal of Portfolio Management, 9, 18-28. https://doi.org/10.3905/jpm.1983.18.

Standard \& Poor's Dow Jones Indices (2013). McGraw-Hill Financial, Available: https://us.spindices.com/documents/factsheets/fs-sp-500-ltr.pdf?force_download=true (June 4, 2014).

Theil, H. (1971). Principles of Econometrics. John Wiley \& Sons, Inc., NY.

Tobin, J. (1958). Estimation of relationships for limited dependent variables. Econometrica, 26(1), 24-36. http://dx.doi.org/10.2307/1907382.

UCLA: Statistical Consulting Group. (2016). Stata Data Analysis Examples Tobit Analysis. Available: http://www.ats.ucla.edu/stat/mult_pkg/faq/general/citingats.htm (January 10, 2016).

Unal, H. (1989). Impact of deposit-rate ceiling changes on bank stock returns. Journal of Money Credit and Banking, 21, 206-220. https://doi.org/10.2307/1992369.

Waheed, A., \& Mathur, I. (1993). The Effects of Announcements of Bank Lending Agreements on the Market Values of U.S. Banks. Financial Management, 22(1). 119-127. https://doi.org/10.2307/3665971.

\section{Appendix A: Mediator and Moderator Variables}

We modify Baron and Kenny's (1986) three-step approach as a test of robustness of our results. ${ }^{43}$

Step 1: We regress CARS against each independent variables to determine whether the relationship is statistically significant (must be). For example, we use total CARs (positive and negative) to represent our dependent variable and regress it against Altman's Z, that is

${ }^{43}$ We thank an anonymous referee for suggesting this approach. 


$$
C_{i t}=\alpha_{i}+\beta_{3 i t} v_{i 3 t}+\beta_{4 i t} v_{i 4 t}+\epsilon_{i t}
$$

where

$$
\begin{aligned}
& v_{i 3 t}=\text { Intermediate Altman's Z for firm i } \\
& v_{i 4 t}=\text { Low Altman's Z for firm i. }
\end{aligned}
$$

Step 2: We develop a Mediator variable using the methodologies of Aharony, Jones \& Swary (1980), Unal (1989) and Waheed and Mathur (1995) who examine risk changes. We split the change in the variance of the returns into two parts: 1) Changes in systematic risk and 2) changes in idiosyncratic (or private) risk. We then estimate the change for the period prior to the event versus the period after the event.

We measure changes in the variance as $\triangle \operatorname{VAR}\left(R_{j}\right)=\frac{\operatorname{VAR}\left(R_{j, p o s t}\right)-\operatorname{VAR}\left(R_{j, p r e}\right)}{\operatorname{VAR}\left(R_{j, \text { pre }}\right)}$

We measure changes in systematic risk $\Delta S Y S_{j}=\frac{\beta_{j, p o s t}-\beta_{j, p r e}}{\beta_{j, p r e}}$

where $\beta_{j, p o s t}$ measures the risk of the jth firm versus that of the market.

We measure changes in private risk as $\Delta$ Private $_{j}=\frac{\operatorname{VAR}\left(\varepsilon_{j, \text { post }}\right)-\operatorname{VAR}\left(\varepsilon_{j, p r e}\right)}{\operatorname{VAR}\left(\varepsilon_{j, \text { pre }}\right)}$.

We then regress the Mediator variable against the independent variable to determine whether it is statistically significant (must be), that is

$$
M E_{i t}=\gamma_{i}+\beta_{3 i t} v_{i 3 t}+\beta_{4 i t} v_{i 4 t}+\epsilon_{i t}
$$

where

$$
M E_{i t}=\Delta \text { Private }_{j}=\left[\frac{\operatorname{VAR}\left(\varepsilon_{j,+2,+102 \text { post }}\right)-\operatorname{VAR}\left(\varepsilon_{j,-102,-2 \text { pre }}\right)}{\operatorname{VAR}\left(\varepsilon_{j,-102,-2 \text { pre }}\right)}\right]
$$

We partition the variance of returns $\left(\operatorname{VAR}\left(R_{j}\right)\right)$ on each firm $j$ 's stock into systematic risk $\left(S Y S_{j}\right)$ and private risk $\left(\operatorname{Var}\left(\varepsilon_{j}\right)\right)$ and use the traditional Brown and Warner event study methodology to develop the slopes and residuals. Next we compute the pre- and post-variances for each event using the residuals and calculate the change in private risk for each event on a pre-announcement, (days (-102 to -2$)$ ), to post-announcement, (days $(+2$ to +102$)$ ) basis.

Step 3: We include the mediator/moderator variable in original regression (both the independent variable and ME should be significant with the slope on the independent variable declining in size). We use a stepwise regression to estimate the mediator and moderator models. The Moderator model is the more general model with both the standalone moderator variable and the interaction terms between the moderator variable and the independent variables. We choose the model that provides the most robust results. We select variables that improve the explanatory power of the regression, i.e., increases the F-statistic and the variable has a t-statistic significant at the $5 \%$ (or better) level. Depending on the results, we 


\section{Macrothink}

Business and Economic Research

ISSN 2162-4860 2018, Vol. 8, No. 1

include those variables that are significant at the $10 \%$ level of significance. See section 4.3 and Table 7 for our results.

\section{Copyright Disclaimer}

Copyright for this article is retained by the author(s), with first publication rights granted to the journal.

This is an open-access article distributed under the terms and conditions of the Creative Commons Attribution license (http://creativecommons.org/licenses/by/3.0/). 